\title{
Effect of initial relative density on the post-liquefaction behaviour of sand
}

\author{
Mehdi Rouholamin ${ }^{1}$, Subhamoy Bhattacharya ${ }^{2}$, Rolando P. Orense ${ }^{3}$
}

\author{
${ }^{1}$ Research Fellow, University of Surrey \\ ${ }^{2}$ Chair in Geomechanics, University of Surrey \\ ${ }^{3}$ Associate Professor, University of Auckland \\ Corresponding author: \\ Subhamoy Bhattacharya \\ Chair in Geomechanics \\ Department of Civil and Environmental Engineering \\ University of Surrey \\ GU2 7XH \\ Email: S.Bhattacharya@surrey.ac.uk
}

Keywords: Liquefaction, multi-stage soil element test, post-liquefaction behaviour, saturated sand

\begin{abstract}
Understanding the behaviour of soils under cyclic/dynamic loading has been one of the challenging topics in geotechnical engineering. The response of liquefiable soils has been well studied however, the post liquefaction behaviour of sands needs better understanding. In this paper, the post liquefaction behaviour of sands is investigated through several series of multistage soil element tests using a cyclic Triaxial apparatus. Four types of sand were used where the sands were first liquefied and then monotonically sheared to obtain stress-strain curves. Results of the tests indicate that the stress-strain behaviour of sand in post liquefaction phase can be modelled as a bi-linear curve using three parameters: the initial shear modulus $\left(G_{1}\right)$, critical state shear modulus $\left(G_{2}\right)$, and post-dilation shear strain $\left(\gamma_{\text {post-dilation }}\right)$ which is the shear strain at the onset of dilation. It was found that the three parameters are dependent on the initial relative density of sands. Furthermore, it was observed that with the increase in the relative density both $G_{1}$ and $G_{2}$ increase and $\gamma_{\text {post-diation }}$ decreases. The practical application of the results is to generate $p-y$ curves for liquefied soil.
\end{abstract}




\section{Introduction}

Liquefaction is one of the most dramatic phenomena which occur in saturated loose sands during an earthquake. Consequently, structures built on top or within the liquefied ground may fail due to either: increased lateral soil pressure, loss of bearing capacity, ground settlement due to post-liquefaction reconsolidation and other associated ground deformations. These consequences depend on a number of various factors, such as site conditions, earthquake characteristics, and the nature of the structure on the site.

The impact of liquefaction to the built environment was introduced to the geotechnical engineering community after the two main earthquakes in 1964 (i.e. Niigata earthquake, Japan and Alaska earthquake, United States). Since then, much research has been carried out to investigate the liquefaction phenomenon using laboratory experiments, model testing and analytical/numerical methods. Most of this research has focused on understanding the mechanism of pore water pressure development and undrained behaviour of sands leading to liquefaction triggering (Iwasaki, 1986; Mohamad and Dobry, 1986; Bouckovalas et al. 2003; Kamata et al. 2009; El Takch et al. 2016; and Wang and Wang, 2017); however, there is a little research done to date in terms of understanding the post-liquefaction response of sand. Yasuda et al. (1999) carried out a series of multi-stage soil element tests on Toyoura sand at different relative densities. Vaid and Thomas (1995) carried out a similar test procedure on Fraser River sand with different relative densities and effective confining stress. In these works, the soil samples were made to liquefy first by applying cyclic loading followed by monotonic shearing under a certain constant strain rate. The results indicated that the liquefied sand showed nearly zero stiffness up to a particular level of strain; after which the soil resistance increased dramatically with strain. Focusing on the effect of axial strain, relative density and effective confining stress on the post-liquefaction behaviour of sands, Sitharam et al. (2009) carried out cyclic triaxial tests on Ahmadabad sand (India). Shamoto et al. (1997), Hyodo et al. (1998), and Kokusho et al. (2004) also carried out similar studies on post-liquefaction behaviour. The main conclusion is undrained stress-strain response of post-liquefaction sand is dependent on relative density of soil. Furthermore, initial confining pressure of the sample have an insignificant influence on the post-liquefaction undrained stress strain response of sands.

After an earthquake, the behaviour of the liquefied soil which is underneath the weight of soil from the upper layer or superstructure would be dilative (Thomas, 1992; and Vaid and Thomas, 1995). As a result, the hardening response observed at large strains can be explained in terms of the dilative response of soil under undrained monotonic shearing. According to Thomas (1992), the stress-strain behaviour of sand at post-liquefaction stage can be divided into three stages as shown in Figure 1: the first region would start immediately after liquefaction (i.e. zero effective stress) and consequently, would indicate zero shear stiffness. Due to the undrained monotonic load, the shear stiffness is gradually increased with the increase in strain, representing the second region. In the third region, the stress-strain curve becomes linear, which represents constant shear stiffness. 


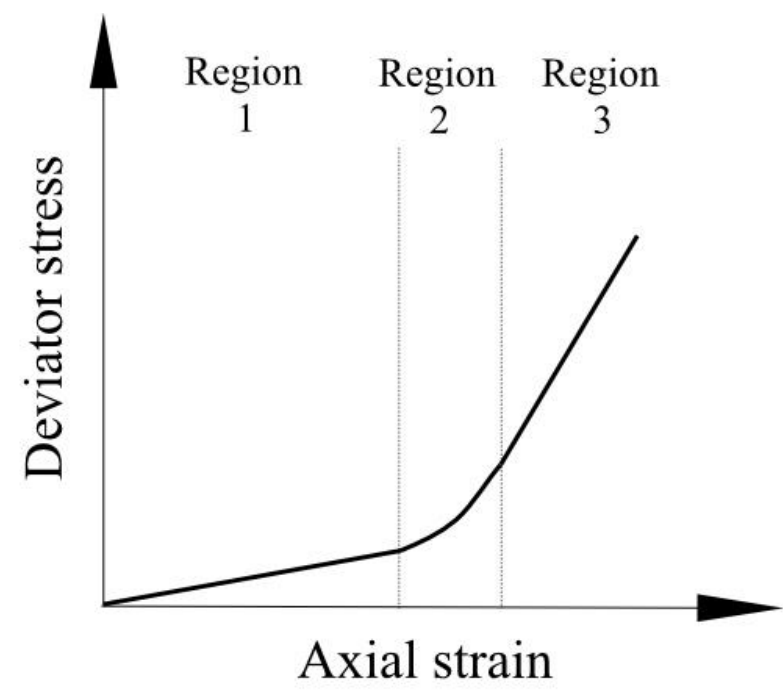

Figure 1: Post liquefaction stress strain curve proposed by Thomas (1992).

The trends of the post-liquefaction stress-strain behaviour were investigated by different researchers. The bi-linear behaviour of the stress-strain curve at post-liquefaction was proposed by Yasuda et al. (1995). Recently, Dash (2010), Lombardi and Bhattacharya (2014), Lombardi et al. (2017) proposed a simple post-liquefaction stress-strain curve defined by four key parameters: the take-off shear strain, initial shear modulus, critical state shear modulus, and maximum shear stress.

In this paper, several series of multi-stage soil element tests were conducted on four different types of sand where the specimens were subjected to undrained monotonic shearing after full liquefaction has been achieved. The sands considered were reconstituted at different relative densities, consolidated under various effective confining stresses, and were made to liquefy under different levels of cyclic shear stress ratio (CSR). The obtained post-liquefaction stressstrain curve was modelled in terms of the initial shear modulus $\left(G_{1}\right)$, critical state shear modulus $\left(G_{2}\right)$ and a parameter called post-dilation shear strain $\left(\gamma_{\text {post-dilation }}\right)$, which is related to the dissipation of excess pore water pressure during the monotonic shearing of the liquefied sand. Based on the tests reported in this study, Sitharam et al (2009) and Lombardi et al (2014) it appears that post-liquefaction stress-strain curve of sand, are mainly affected by the initial relative density while the effect of initial effective confining stress was negligible (at least within the range considered in the tests). Thus, the parameters to model the post-liquefaction behaviour can be expressed in terms of the initial relative density of the sand. Such a simplified way of estimating the stress-strain curve of liquefied sand has many applications, such as in investigating lateral spreading of liquefied soil, studying foundation settlements and estimating p-y curves for the analysis of soil-structure interaction.

\section{Materials and experimental method}

Four types of sand were used to carry out the experimental investigation; two commercially available sands, Redhill-110 sand (UK) and silica sand No. 8 (Japan), which are typically used in laboratory studies; and two natural sands from India, Assam sand and Ganga sand. Figure 2 shows the microscopic photos of the sands while their index properties based on ASTM standards (D4253, D4254, and D854) are listed in Table 1. The grain size distribution curves 
of the sands are shown in Figure 2, where it is observed that all sands have uniform grain size distribution and low fines content. Also indicated in Figure 3 the range of grain size distributions of sands which are deemed to have a high potential for liquefaction as well as the potential for liquefaction. This graph is based on past historical earthquakes in Japan and stipulated in the design code for port and harbour facilities (PHRI, 1997).

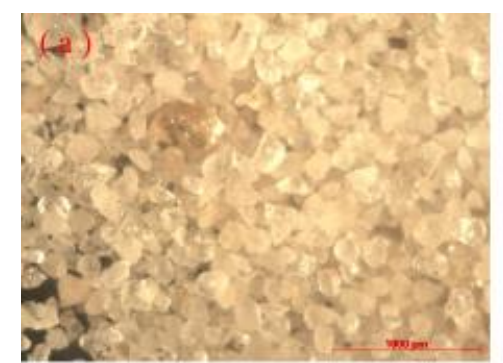

(a ) Redhill-110 sand

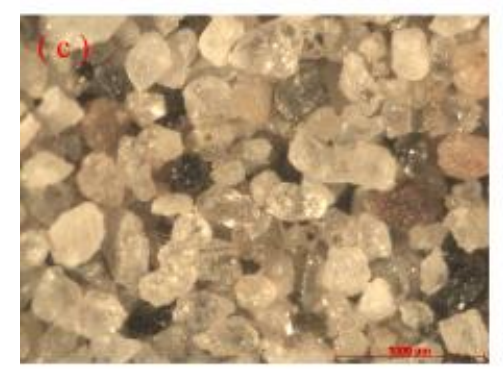

(c) Assam sand (India)

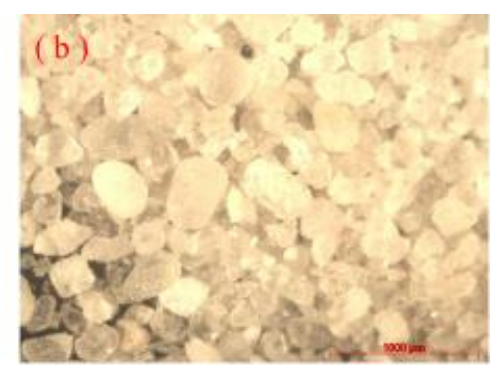

(b) Silica sand No. 8 (Japan)

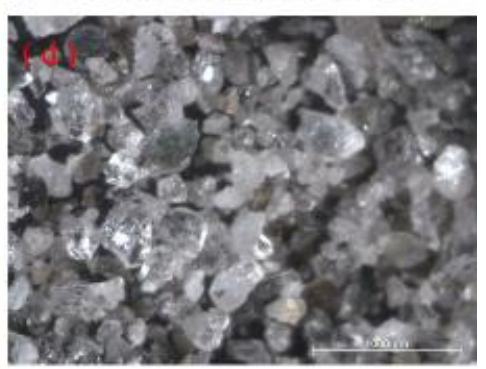

(d) Ganga sand (India)

Figure 2: Microscopic photo of sands used in the tests: (a) Redhill-110 sand; (b) Silica sand No.8 (Japan); (c) Assam sand (India); and (d) Ganga sand (India).

Table 1: Properties of sands used in the tests.

\begin{tabular}{|c|c|c|c|c|}
\hline Sand name & $\begin{array}{c}\text { Specific } \\
\text { gravity, } G_{s}\end{array}$ & $\begin{array}{c}\text { Mean } \\
\text { diameter, } \\
D_{50}(\mathrm{~mm})\end{array}$ & $\begin{array}{c}\text { Maximum } \\
\text { void ratio, } e_{\max }\end{array}$ & $\begin{array}{c}\text { Minimum } \\
\text { void ratio, } e_{\min }\end{array}$ \\
\hline Redhill-110 (UK) & 2.65 & 0.18 & 1.035 & 0.608 \\
\hline Silica sand No. 8 (Japan) & 2.65 & 0.16 & 1.385 & 0.797 \\
\hline Assam sand (India) & 2.68 & 0.30 & 0.962 & 0.622 \\
\hline Ganga sand (India) & 2.67 & 0.35 & 1.003 & 0.8534 \\
\hline
\end{tabular}




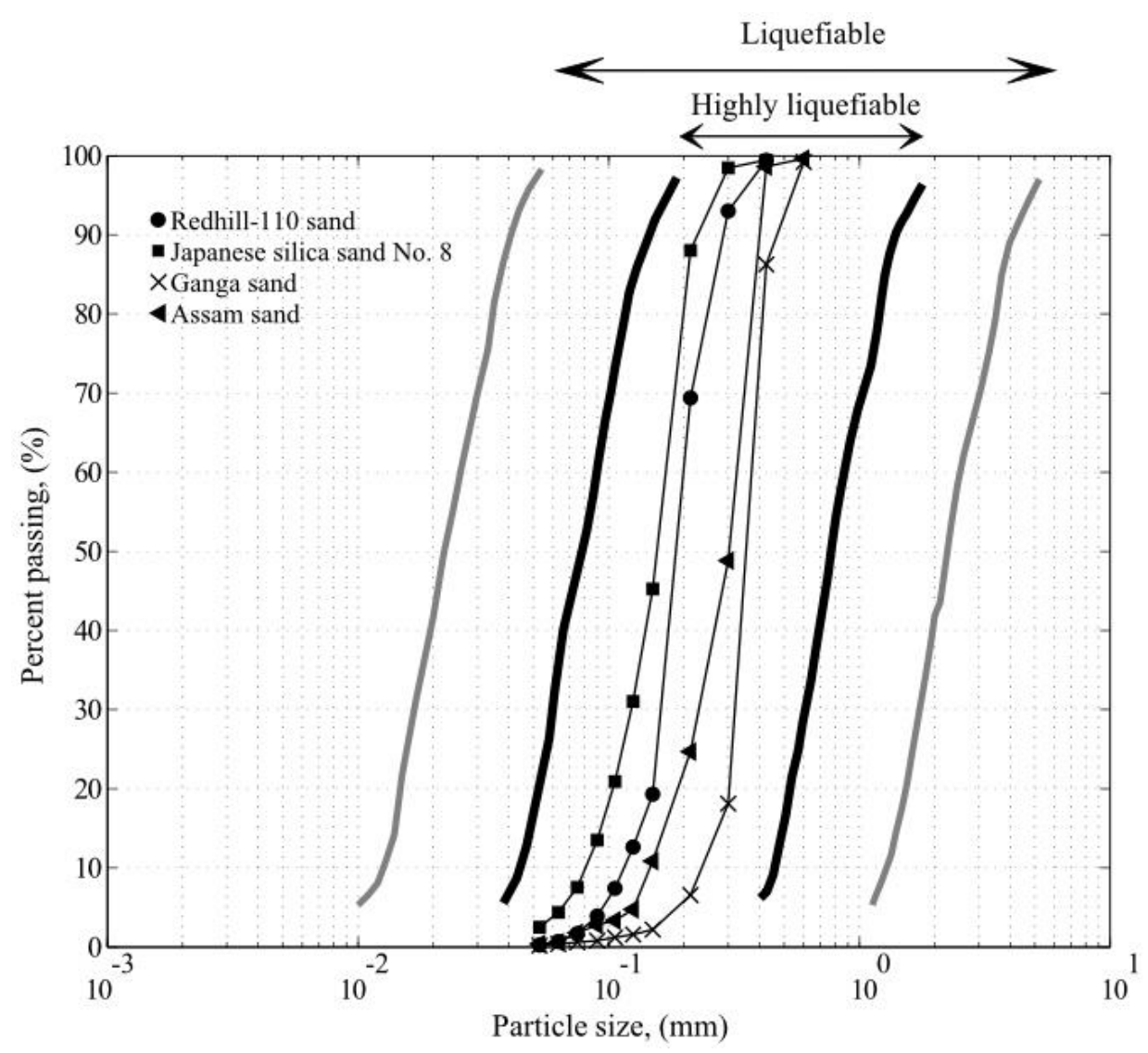

Figure 3: Particle size distribution curves of the sands used plotted with respect to range of particle sizes observed to be susceptible to liquefaction (Modified from PHRI, 1997).

Several series of advanced soil testing (i.e. multi-stage soil element test) using Cyclic Triaxial apparatus were carried out at the SAGE (Surrey Advanced Geotechnical Engineering) Laboratory at the University of Surrey. In these experiments, the samples were prepared using the dry pluviation method. Silicon grease was applied around the pedestal in order to decrease the friction between the membrane and the pedestal. The sample size was $100 \mathrm{~mm}$ in diameter and $200 \mathrm{~mm}$ in height. After preparing the specimen, small negative pressure of $-10 \mathrm{kPa}$ was applied in order to remove the mould from the sample. When the mould was removed, the cell chamber was then placed on the base of the frame. The negative pressure was then removed and the cell pressure $(40 \mathrm{kPa})$ was applied to the inside the cell chamber simultaneously. The specimen was then flushed with de-aired water from bottom to the top in order to replace the air bubbles with de-aired water followed by saturation. The specimen was saturated with high back pressure (i.e. $480 \mathrm{kPa}$ ). The duration of saturation process was different for various types of sands. For finer sands, this process to saturate under such high level of confining pressure took longer, around 24 to 48 hours. Using this procedure, the measured B-value $\left(B=\Delta u / \Delta \sigma_{3}\right.$ , where $\Delta \sigma_{3}$ is an increase in confining stress applied to the specimen and $\Delta u$ is the resulting change in pore water pressure) after saturation was around 0.95 to 0.97 . The sample was then isotropically consolidated in order to obtain the target effective confining stress $\left(\sigma_{c}^{\prime}\right)$. The load was applied by an electro-mechanical motor placed on the top of the triaxial frame. In addition to the axial load, the cell pressure, pore pressure, volume change and axial displacement were 
all monitored electronically and these data were recorded via a data acquisition system onto a computer for later analysis.

As illustrates in Figure 4, in these tests, undrained stress-controlled sinusoidal cyclic loading with frequency of $0.1 \mathrm{~Hz}$ was initially applied in order to liquefy the soil sample. This frequency was chosen to reduce the effect of viscosity following the work of Yasuda and Soga (1984), Hyodo et al. (1998) and Lombardi et al. 2014. The amplitude of the cyclic load was varied for the cases investigated. This cyclic load was stopped when the onset of liquefaction was monitored. For loose to medium sand, the onset of liquefaction occurs when the condition of zero effective stress (mean effective stress) was achieved, i.e. the "initial liquefaction" as proposed by Seed and Lee (1966). While for dense sand, the onset of liquefaction is defined as the development of 5\% double amplitude of axial strain (Ishihara, 1993). Note that in dense sand, the condition of zero effective stress occurred only momentarily. Once the specimen liquefied, strain-controlled monotonic load was then applied under undrained condition to obtain the stress-strain curve of the liquefied sand keeping the drainage valve closed. The monotonic load was applied at a rate of $0.1 \%$ axial strain per minute. Such multi-stage tests on the four types of sands were conducted under different conditions of initial relative densities (between $30 \%$ and $70 \%$ ), effective confining stress (between $50 \mathrm{kPa}$ and $150 \mathrm{kPa}$ ), and applied cyclic deviator stress (between $20 \mathrm{kPa}$ and $50 \mathrm{kPa}$ ) in order to have a different levels of Cyclic Stress Ratio (CSR). This parameter is the ratio of shear stress over effective confining stress ( $\left.C S R=\frac{\tau}{2 \sigma_{c}^{\prime}}\right)$ used in the Triaxial test. Table 2 lists the conditions considered in the tests. Note that the effective confining pressure investigated ranged from $50-150 \mathrm{kPa}$, corresponding to the usual depths of soil considered for liquefaction analysis. The effect of much higher confining pressure was not considered in the testing programme. It may be noted that the considered range of effective confining stress is limited to a maximum of $150 \mathrm{kPa}$ and therefore the presented results may not cover the whole behaviour of the considered material particularly the behaviour of soils at deeper depths.

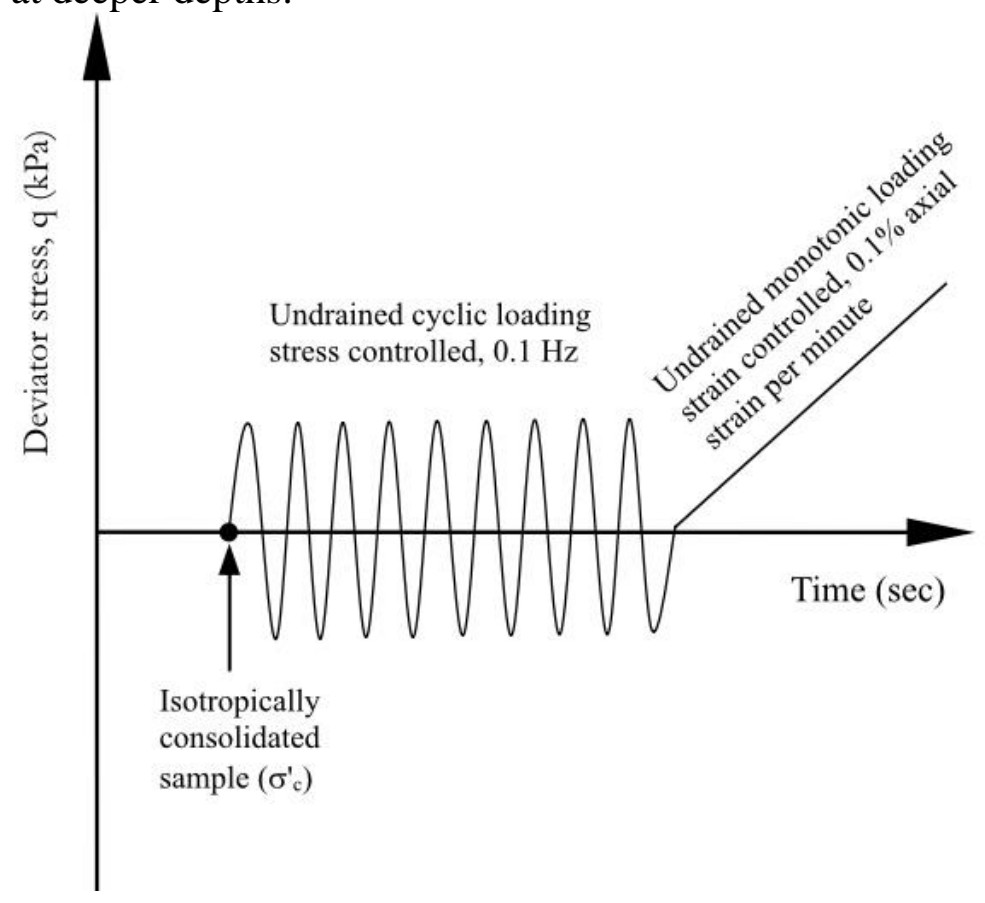

Figure 4: Testing scheme adopted for the multi-stage element test. 
Table 2: list of multi-stage soil element tests.

\begin{tabular}{|c|c|c|c|c|c|}
\hline Test ID & Sand type & $\begin{array}{c}\text { Relative } \\
\text { density, } \\
D_{r}(\%)\end{array}$ & $\begin{array}{c}\text { Effective } \\
\text { confining stress, } \\
\sigma_{c}^{\prime}(\mathrm{kPa})\end{array}$ & $\begin{array}{l}\text { Cyclic } \\
\text { deviator } \\
\text { stress, } q \\
(\mathrm{kPa})\end{array}$ & $\begin{array}{l}\text { Cyclic Stress } \\
\text { Ratio, (CSR) }\end{array}$ \\
\hline MR-1 & Redhill-110 & 30 & 97 & 30 & 0.154 \\
\hline MR-2 & Redhill-110 & 30 & 105 & 30 & 0.143 \\
\hline MR-3 & Redhill-110 & 30 & 125 & 30 & 0.12 \\
\hline MR-4 & Redhill-110 & 30 & 91 & 30 & 0.165 \\
\hline MR-5 & Redhill-110 & 30 & 102 & 30 & 0.147 \\
\hline MR-6 & Redhill-110 & 30 & 51 & 30 & 0.294 \\
\hline MR-7 & Redhill-110 & 35 & 63 & 30 & 0.238 \\
\hline MR-8 & Redhill-110 & 35 & 100 & 30 & 0.150 \\
\hline MR-9 & Redhill-110 & 35 & 67.5 & 30 & 0.222 \\
\hline MR-10 & Redhill-110 & 35 & 50 & 30 & 0.300 \\
\hline MR-11 & Redhill-110 & 45 & 83 & 30 & 0.181 \\
\hline MR-12 & Redhill-110 & 45 & 96.5 & 30 & 0.155 \\
\hline MR-13 & Redhill-110 & 45 & 102 & 30 & 0.147 \\
\hline MR-14 & Redhill-110 & 50 & 96 & 30 & 0.156 \\
\hline MR-15 & Redhill-110 & 50 & 90 & 30 & 0.166 \\
\hline MR-16 & Redhill-110 & 50 & 87 & 30 & 0.172 \\
\hline MR-17 & Redhill-110 & 50 & 85 & 30 & 0.176 \\
\hline MR-18 & Redhill-110 & 50 & 94.5 & 30 & 0.159 \\
\hline MR-19 & Redhill-110 & 50 & 105.5 & 30 & 0.142 \\
\hline MR-20 & Redhill-110 & 50 & 113 & 30 & 0.133 \\
\hline MR-21 & Redhill-110 & 50 & 104 & 30 & 0.144 \\
\hline MR-22 & Redhill-110 & 55 & 97 & 30 & 0.155 \\
\hline MR-23 & Redhill-110 & 55 & 94 & 30 & 0.166 \\
\hline MR-24 & Redhill-110 & 55 & 95.4 & 40 & 0.209 \\
\hline MR-25 & Redhill-110 & 55 & 94 & 30 & 0.159 \\
\hline MR-26 & Redhill-110 & 55 & 107 & 50 & 0.234 \\
\hline MR-27 & Redhill-110 & 55 & 102 & 30 & 0.147 \\
\hline MR-28 & Redhill-110 & 55 & 98.5 & 30 & 0.152 \\
\hline MR-29 & Redhill-110 & 55 & 51 & 30 & 0.294 \\
\hline MR-30 & Redhill-110 & 55 & 98 & 30 & 0.153 \\
\hline MR-31 & Redhill-110 & 55 & 50 & 20 & 0.200 \\
\hline MR-32 & Redhill-110 & 60 & 94 & 30 & 0.159 \\
\hline MR-33 & Redhill-110 & 60 & 103.5 & 30 & 0.145 \\
\hline MR-34 & Redhill-110 & 60 & 104 & 30 & 0.144 \\
\hline MR-35 & Redhill-110 & 65 & 109 & 30 & 0.137 \\
\hline MR-36 & Redhill-110 & 65 & 91 & 30 & 0.165 \\
\hline MR-37 & Redhill-110 & 70 & 102 & 30 & 0.147 \\
\hline MR-38 & Redhill-110 & 80 & 99 & 30 & 0.152 \\
\hline MR-39 & Silica sand No. 8 & 30 & 98.5 & 30 & 0.152 \\
\hline MR-40 & Silica sand No. 8 & 40 & 99 & 30 & 0.152 \\
\hline MR-41 & Silica sand No. 8 & 40 & 99.2 & 25 & 0.126 \\
\hline MR-42 & Silica sand No. 8 & 50 & 98 & 40 & 0.206 \\
\hline MR-43 & Silica sand No. 8 & 50 & 101.2 & 30 & 0.148 \\
\hline MR-44 & Silica sand No. 8 & 50 & 50 & 30 & 0.300 \\
\hline MR-45 & Silica sand No. 8 & 50 & 150 & 30 & 0.100 \\
\hline
\end{tabular}




\begin{tabular}{|l|l|c|c|c|c|}
\hline Test ID & Sand type & $\begin{array}{c}\text { Relative } \\
\text { density, } \\
D_{r}(\%)\end{array}$ & $\begin{array}{c}\text { Effective } \\
\text { confining stress, } \\
\sigma^{\prime}{ }_{c}(\mathrm{kPa})\end{array}$ & $\begin{array}{c}\text { Cyclic } \\
\text { deviator } \\
\text { stress, } q \\
(\mathrm{kPa})\end{array}$ & $\begin{array}{c}\text { Cyclic Stress } \\
\text { Ratio, }(\mathrm{CSR})\end{array}$ \\
\hline MR-46 & Silica sand No. 8 & 70 & 97 & 30 & 0.155 \\
\hline MR-47 & Silica sand No. 8 & 70 & 97 & 40 & 0.206 \\
\hline MR-48 & Silica sand No. 8 & 70 & 100 & 25 & 0.125 \\
\hline MR-49 & Silica sand No. 8 & 80 & 99 & 50 & 0.253 \\
\hline MR-50 & Assam sand & 35 & 100 & 30 & 0.150 \\
\hline MR-51 & Assam sand & 45 & 101 & 30 & 0.148 \\
\hline MR-52 & Assam sand & 50 & 99.5 & 30 & 0.150 \\
\hline MR-53 & Assam sand & 55 & 100 & 30 & 0.150 \\
\hline MR-54 & Assam sand & 60 & 96.7 & 40 & 0.206 \\
\hline MR-55 & Assam sand & 65 & 98.5 & 30 & 0.152 \\
\hline MR-56 & Assam sand & 70 & 98 & 50 & 0.255 \\
\hline MR-57 & Assam sand & 75 & 99 & 40 & 0.202 \\
\hline MR-58 & Ganga sand & 30 & 101 & 30 & 0.148 \\
\hline MR-59 & Ganga sand & 35 & 100 & 30 & 0.150 \\
\hline MR-60 & Ganga sand & 45 & 100.5 & 30 & 0.149 \\
\hline MR-61 & Ganga sand & 45 & 97 & 30 & 0.154 \\
\hline MR-62 & Ganga sand & 50 & 99.5 & 30 & 0.150 \\
\hline MR-63 & Ganga sand & 50 & 100 & 40 & 0.200 \\
\hline MR-64 & Ganga sand & 55 & 98.7 & 45 & 0.227 \\
\hline MR-65 & Ganga sand & 60 & 100 & 40 & 0.200 \\
\hline MR-66 & Ganga sand & 65 & 100 & 45 & 0.225 \\
\hline MR-67 & Ganga sand & 70 & 100 & 40 & 0.200 \\
\hline & & & & & \\
\hline
\end{tabular}

\section{Results and discussion}

Typical results of multi-stage soil element tests are discussed in this section, representing the response of the different sands used. Figures 5-12 correspond to the results for mediumdense sand samples $\left(D_{r}=50 \%\right)$ which were isotropically consolidated under $100 \mathrm{kPa}$ effective confining stress and cyclically sheared with 30kPa deviator stress. Figures 5, 7, 9, and 11 present the stress paths of the samples during the multi-stage test and stress-strain curves during the cyclic phase while Figures 6, 8, 10, and 12 depict the variation of the excess pore water pressure ratio, effective confining stress, and axial strain with the number of cycles of cyclic loading.

Figure 5 shows $p^{\prime}-q$ stress path and the stress-strain curve of the Redhill-110 sand sample under multi-stage test. These $p^{\prime}$ and $q$ stresses represent the mean effective stress and the deviator stress, respectively (Roscoe et al. 1958). These stresses can be calculated by the following equations:

$$
p^{\prime}=\frac{\left(\sigma_{a}^{\prime}+2 \sigma_{c}^{\prime}\right)}{3}
$$

$q=\sigma_{a}^{\prime}-\sigma_{c}^{\prime}$

where $\sigma^{\prime}{ }_{a}$ and $\sigma^{\prime}{ }_{c}$ are the axial and the effective confining stresses, respectively.

As can be seen from Figure 5 and 6(c), the development of axial strain in the sample is slow during the early part of cyclic loading; then large axial strain is mobilised and the sample liquefied at nearly 10 cycles. Figure 6 shows the changes in excess pore water pressure ratio $\left(r_{u}\right)$, effective confining stress $\left(\sigma_{c}^{\prime}\right)$, and axial strain $\left(\varepsilon_{a}\right)$ with increasing number of cycles. With the generation of the excess pore water pressure, the effective confining stress decreases; 
consequently, the axial strain in the soil increases. The onset of liquefaction was observed at the condition of zero effective stress (i.e. $r_{u}=1$ ).
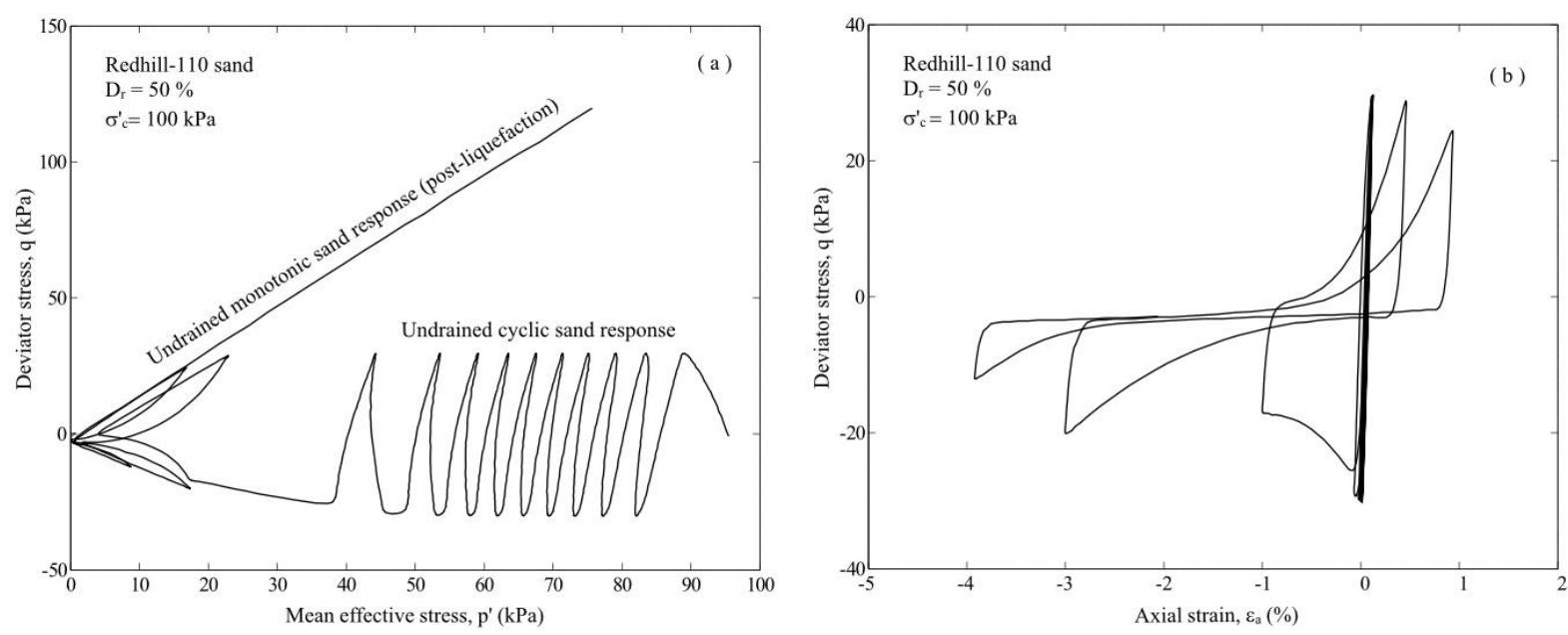

Figure 5: Cyclic behaviour of Redhill-110 sand: (a) stress path; and (b) deviator stress versus axial strain during cyclic phase (Test MR-21).
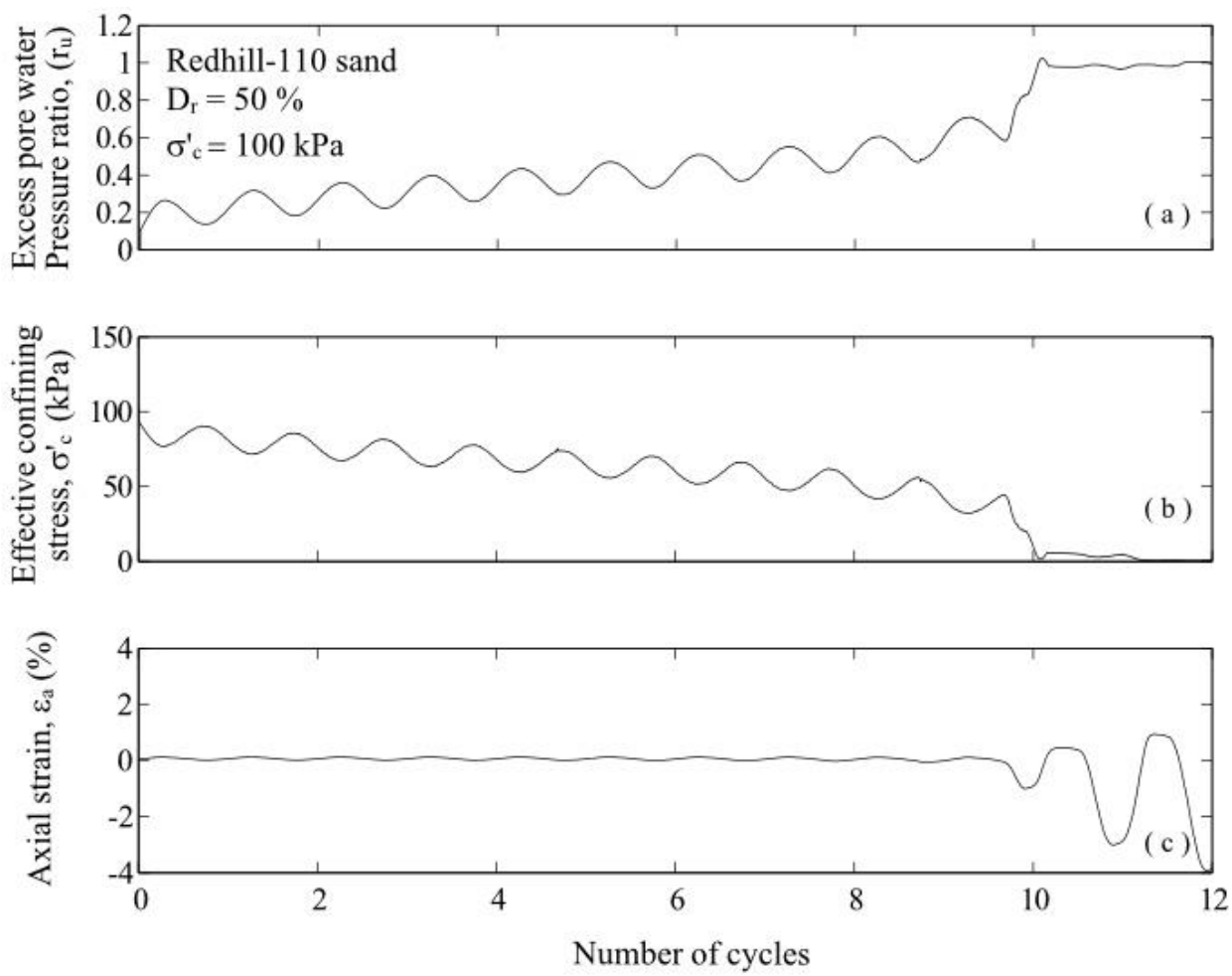

Figure 6: Variation of (a) excess pore water pressure ratio; (b) effective confining stress; and

(c) axial strain with the number of cycles of loading for Redhill-110 sand (Test MR-21).

The multi-stage test results for the medium dense sample of Japanese silica sand No. 8, which was isotopically consolidated under $100 \mathrm{kPa}$ and sheared under $30 \mathrm{kPa}$ of deviator stress, 
is shown in Figures 7 and 8. As can be seen from Figure 7, the mean effective stress decreases from the initial value towards zero during the undrained cyclic loading. The stress-strain curve has closed loops at the beginning of the shearing; however, once the sample liquefies (after about 8 cycles), the loops become banana in shape and large deformation occurs. Figure 8 shows the changes in excess pore water pressure ratio $\left(r_{u}\right)$, effective confining stress $\left(\sigma_{c}^{\prime}\right)$, and axial strain $\left(\varepsilon_{a}\right)$ with increasing the number of cycles. From the figure, it is clear that the sample was liquefied at the condition of zero effective stress (i.e. $r_{u}=1$ ).
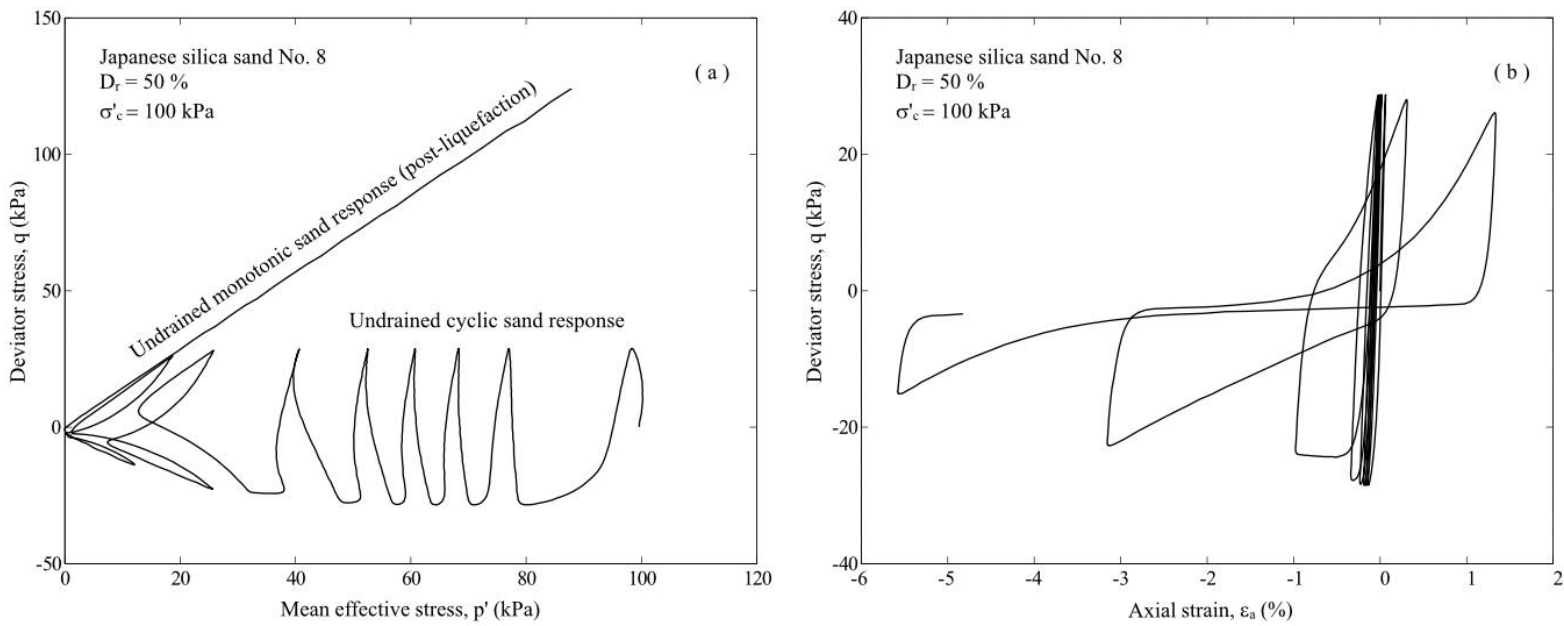

Figure 7: Cyclic behaviour of Japanese silica sand No.8: (a) stress path; and (b) deviator stress versus axial strain during cyclic phase (Test MR-43).
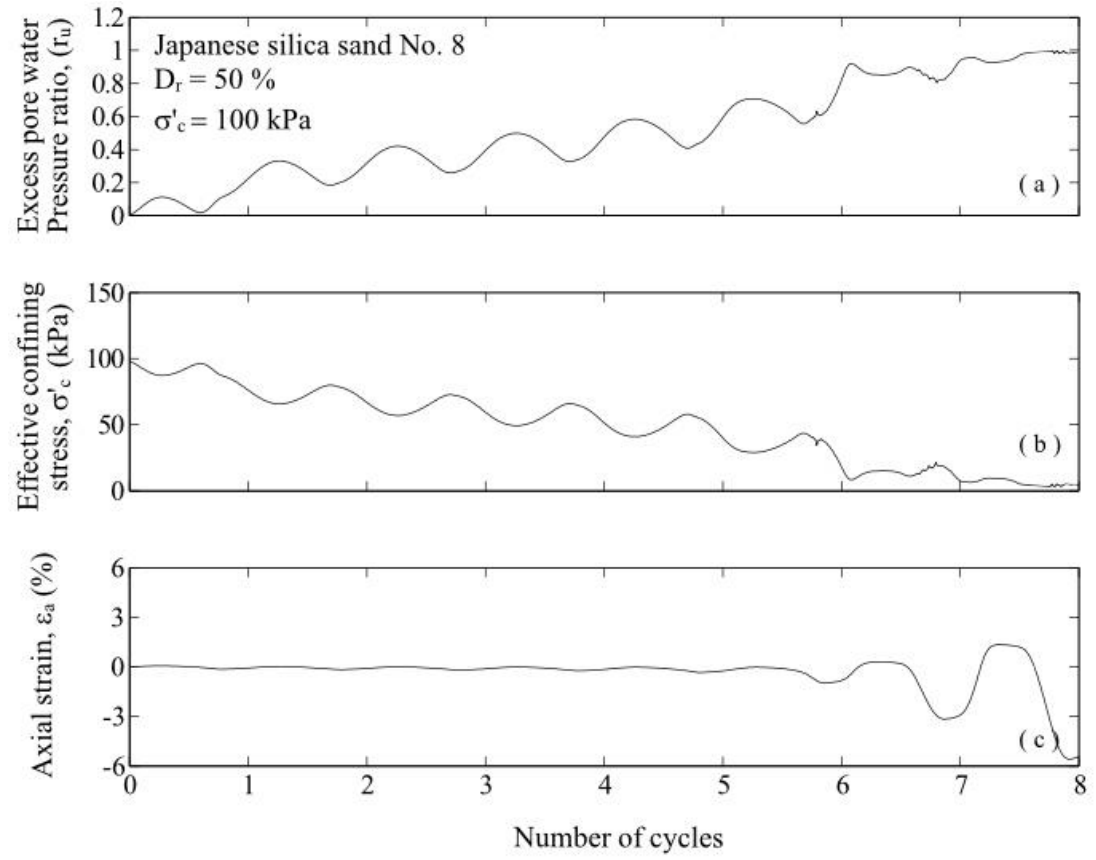

Figure 8: Variation of (a) excess pore water pressure ratio; (b) effective confining stress; and (c) axial strain with the number of cycles of cyclic loading for Japanese silica sand (Test MR43). 
Figures 9 and 10 display the results for medium dense Assam sand under similar initial effective confining pressure and amplitude of cyclic deviator stress. From Figure 9, the sand liquefied after around 23 cycles while from Figure 10, it is clear that the sample liquefied with the development of $5 \%$ double amplitude axial strain. The condition of momentary zero effective stress was observed in this test.
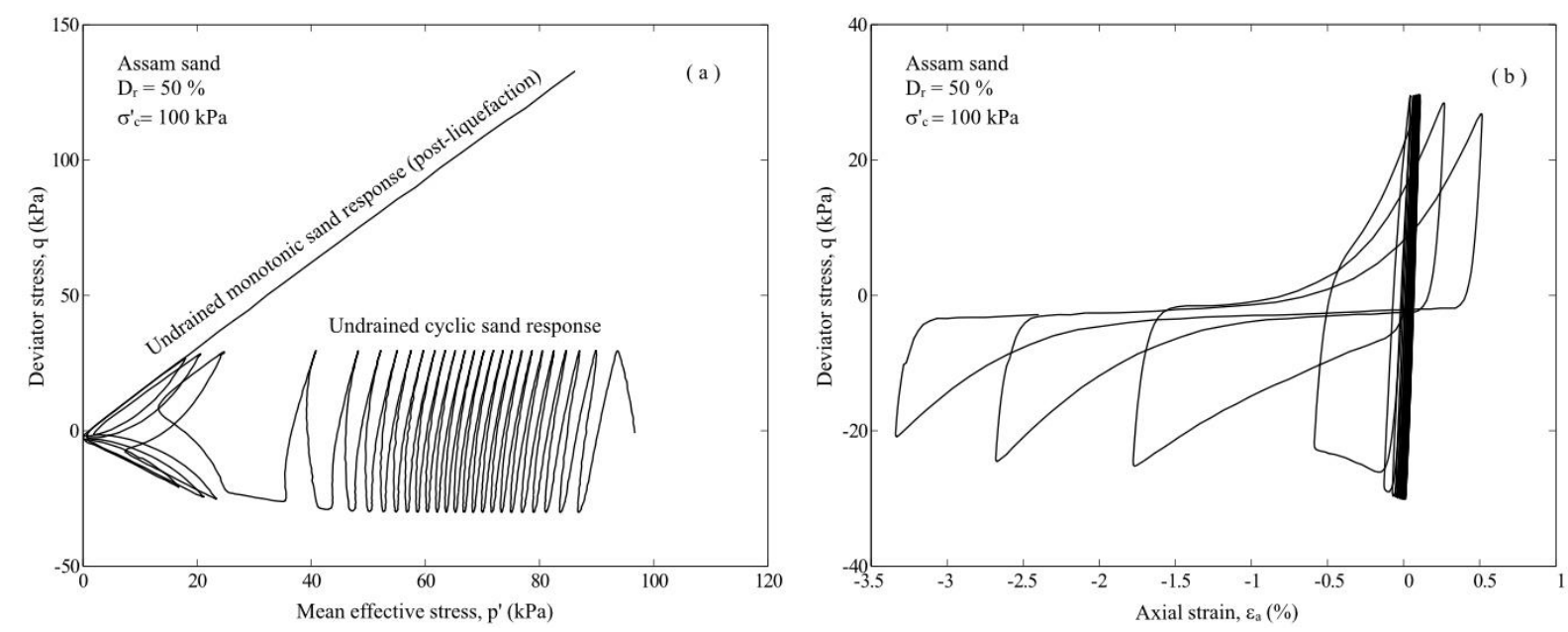

Figure 9: Cyclic behaviour of Assam sand: (a) stress path; and (b) deviator stress versus axial strain during cyclic phase (Test MR-52).
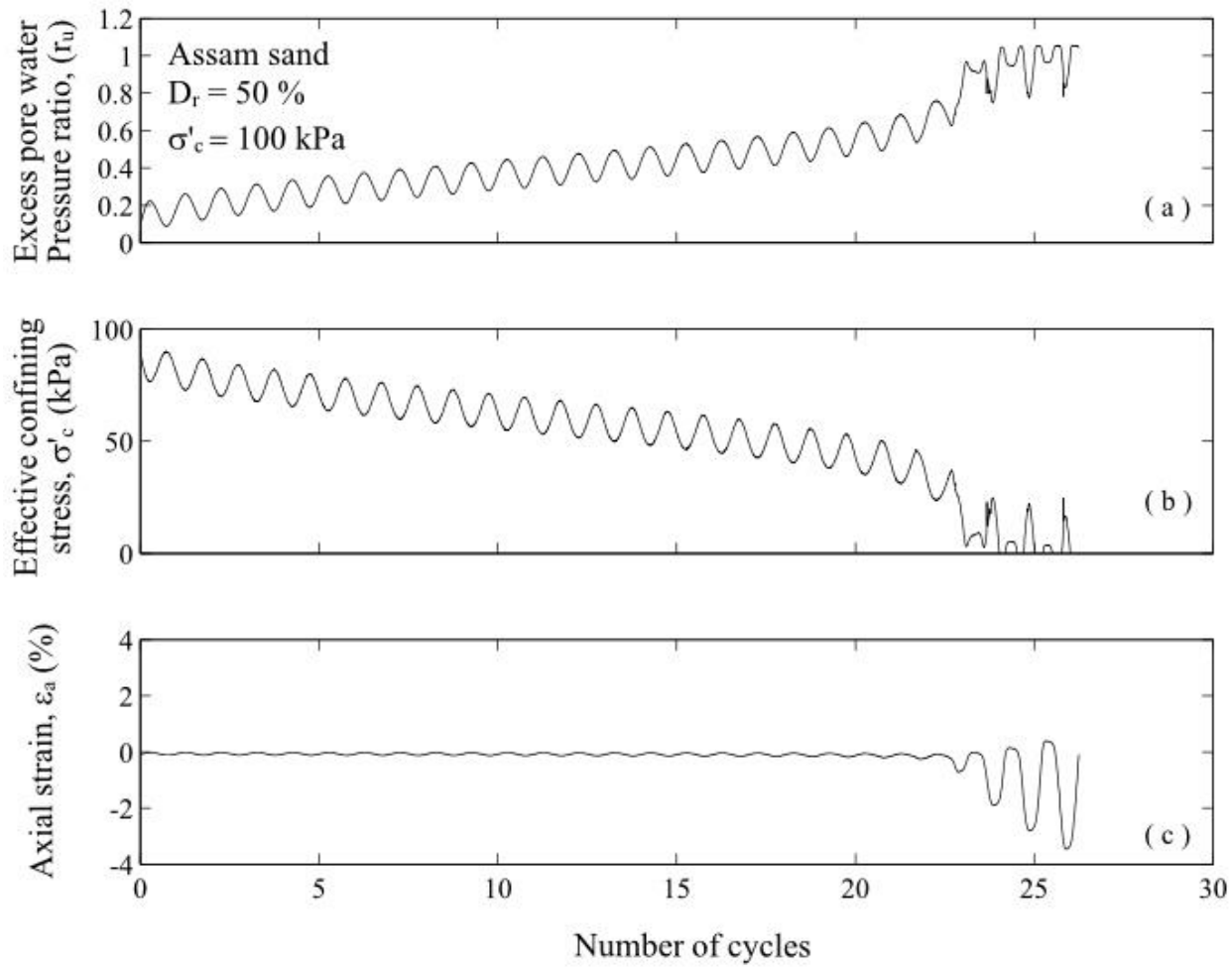

Figure 10: Variation of (a) excess pore water pressure ratio; (b) effective confining stress; and (c) axial strain with the number of cyclic loading for Assam sand (Test MR-52). 
Finally, the results for Ganga sand under the same conditions are presented in Figures 11 and 12, where it can be seen that the behaviour of this sand is similar to Assam sands in terms of the onset of liquefaction; however, it liquefied in only 20 cycles.
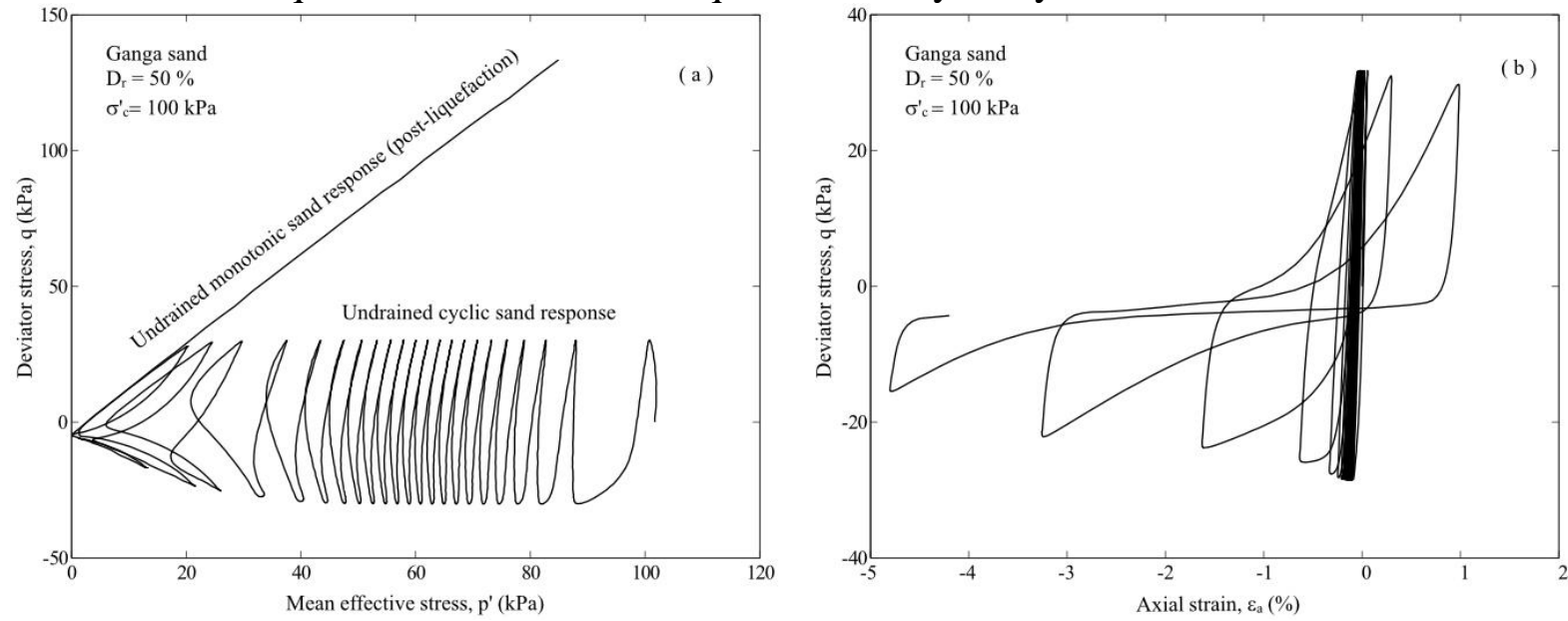

Figure 11: Cyclic behaviour of Ganga sand: (a) stress path; and (b) deviator stress versus axial strain during cyclic phase (Test MR-62).
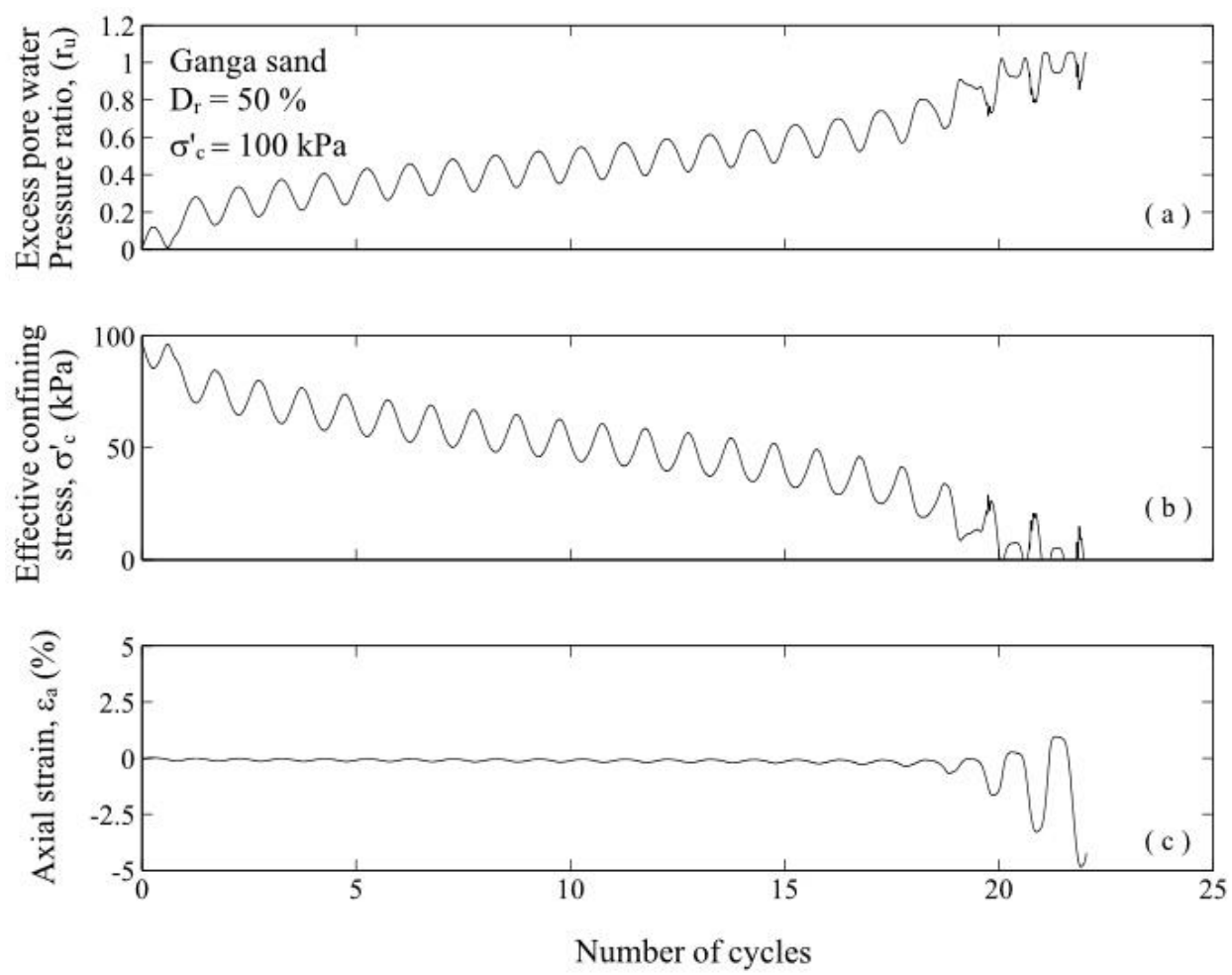

Figure 12: Variation of (a) excess pore water pressure ratio; (b) effective confining stress; and (c) axial strain with the number of cyclic loading for Ganga sand (Test MR-62).

A specimen of Ganga sand with the same relative density and effective confining stress $(50 \%$ and $100 \mathrm{kPa}$, respectively) was tested under higher deviator stress $(40 \mathrm{kPa})$. The results are plotted in Figures 13 and 14. As shown in Figure 13, Ganga sand under higher deviator stress (i.e. $40 \mathrm{kPa}$ ) liquefied in less number of cycles. Having constant parameters of relative density and effective confining stress, as the deviator stress increases, the number of cycles required to initiate liquefaction decreases. From Figure 14(b), the condition of momentarily 
zero effective stress due to cyclic mobility was observed. Therefore, the onset of liquefaction was considered to correspond to 5\% double amplitude axial strain.
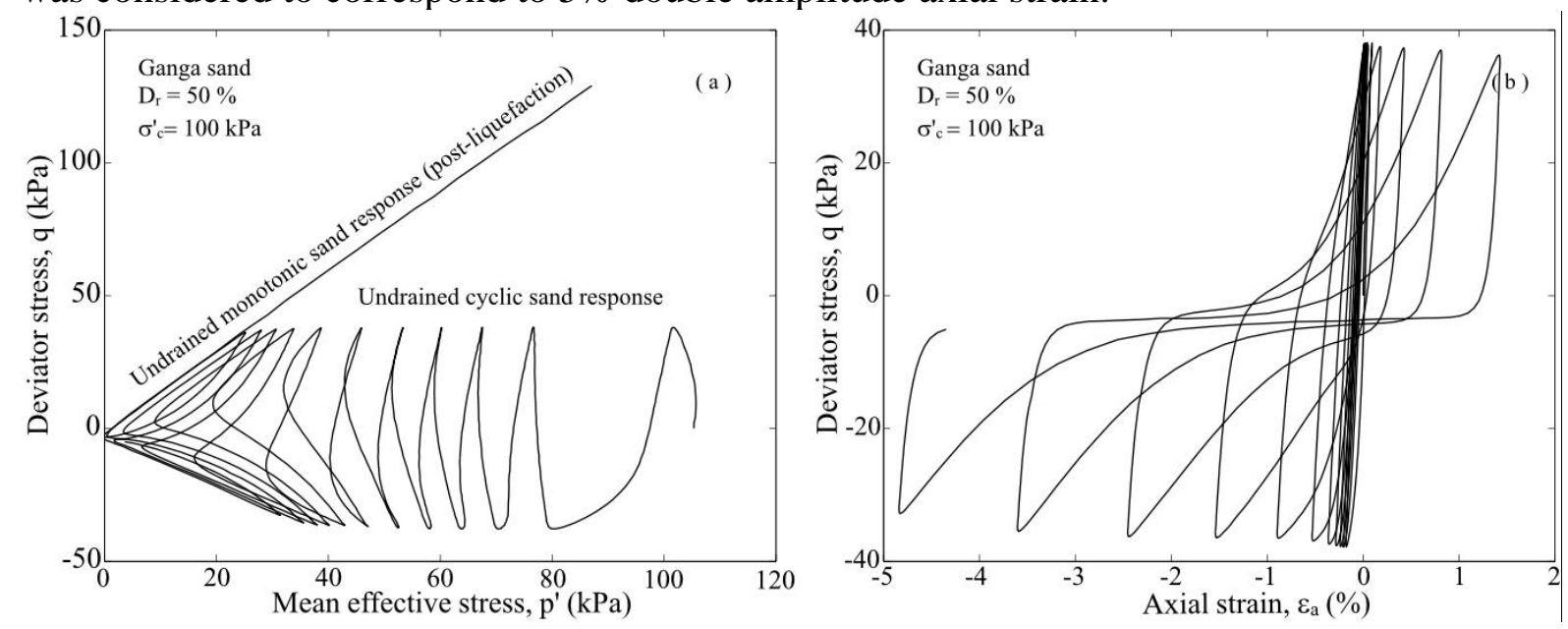

Figure 13: Cyclic behaviour of Ganga sand under deviator stress of 40kPa: (a) stress path; and (b) deviator stress versus axial strain during cyclic phase (Test MR-63).
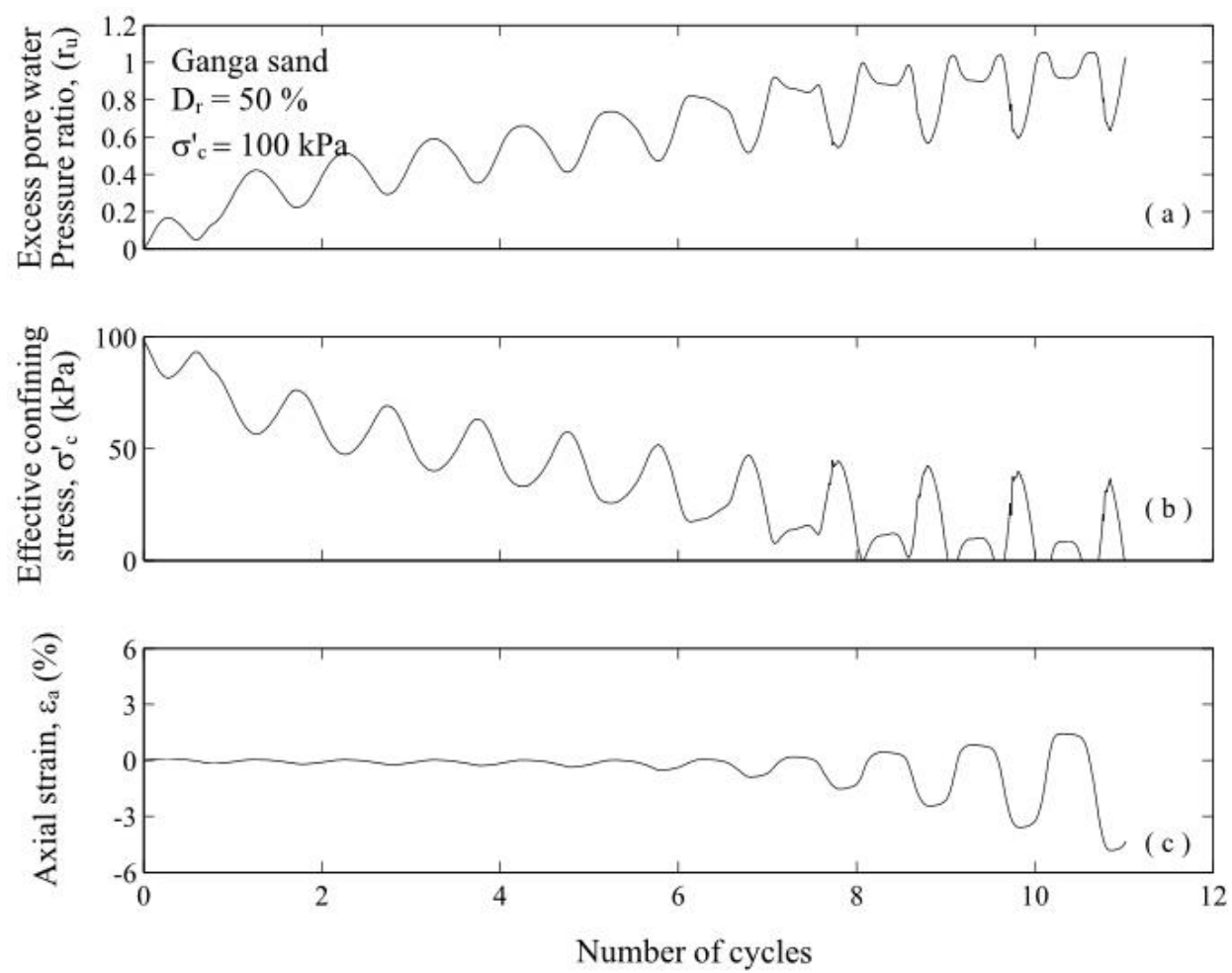

Figure 14: Variation of (a) excess pore water pressure ratio; effective confining stress; and (c) axial strain with the number of cyclic loading for Ganga sand $(q=40 \mathrm{kPa})$ (Test MR-63).

\section{Post-liquefaction characteristics of sand}

When the undrained monotonic load is applied to the liquefied sand, the sand sample shows very low stiffness at the beginning of the loading, until a certain level of axial strain is reached. After that, the resistance of the sand specimen increases dramatically due to dilatancy induced by particle rearrangement. The axial strain is dependent on the initial density of the sand when such increase in resistance occurs. Figures 15-18 show the post-liquefaction response of the four different types of sands for the same level of CSR in terms of variation of deviatoric stress 
and excess pore water pressure with axial strain. From the figures, it can be seen that the sand specimen has no initial stiffness up to a certain level of axial strain.

Redhill-110 sand $\sigma_{\mathrm{c}}^{\prime}=100 \mathrm{kPa}$
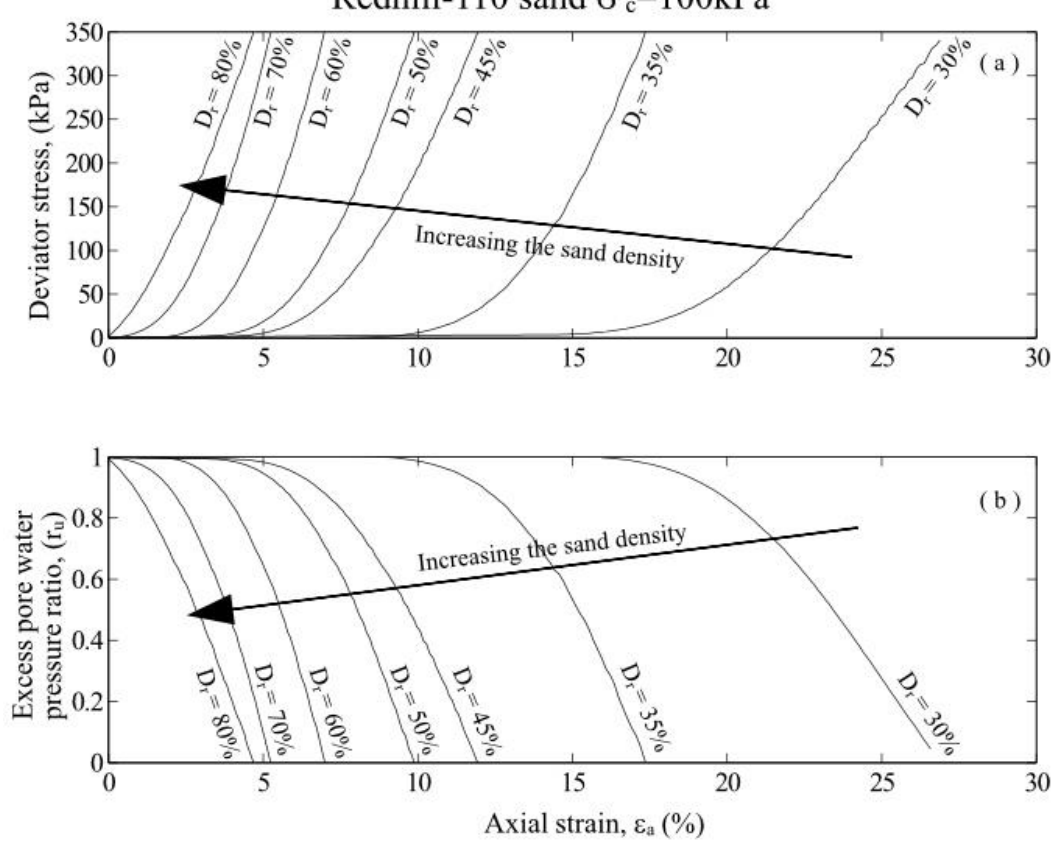

Figure 15: Post liquefaction response of Redhill-110 sand (CSR=0.15). Variation of: (a) deviator stress; and (b) excess pore water pressure ratio $\left(r_{u}\right)$ with axial strain (Tests MR-5,

MR-8, MR-13, MR-14, MR-33, MR-37 and MR-38).
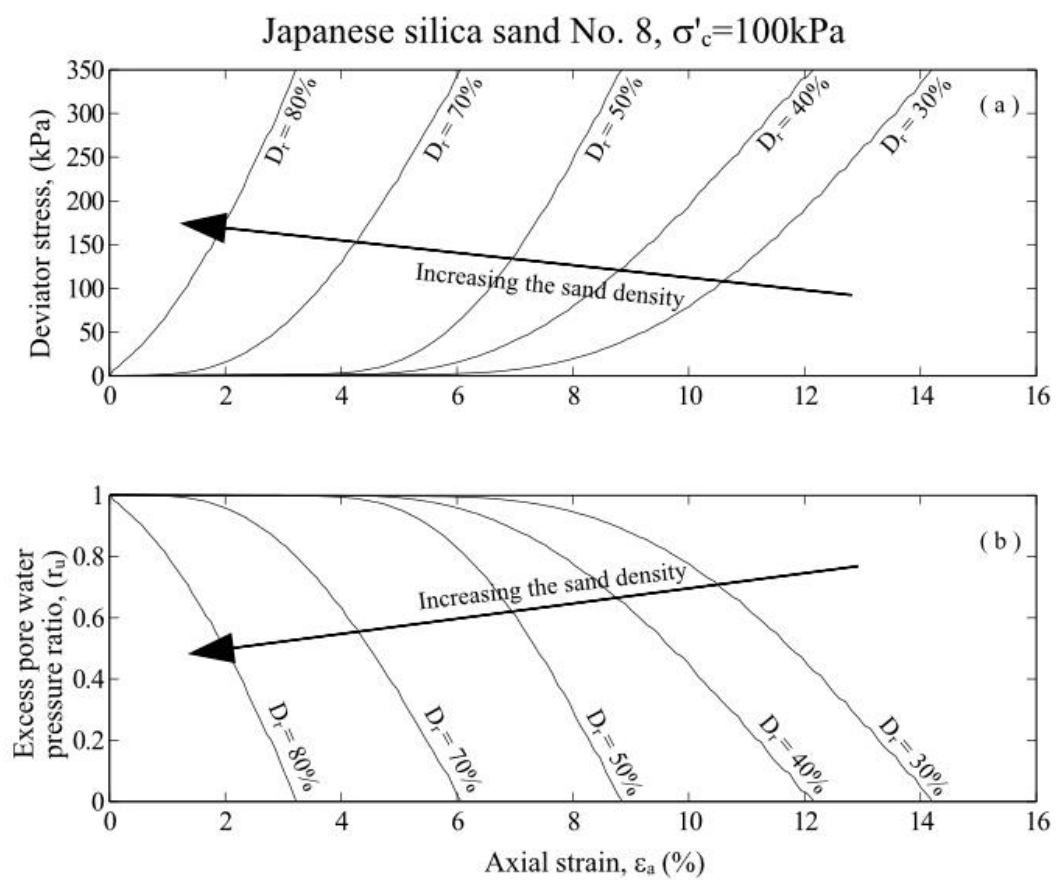

Figure 16: Post liquefaction response of Japanese silica sand (CSR=0.15). Variation of: (a) deviator stress; and (b) excess pore water pressure ratio $\left(r_{u}\right)$ with axial strain (Tests MR-39, MR-40, MR-43, MR-48 and MR-49). 

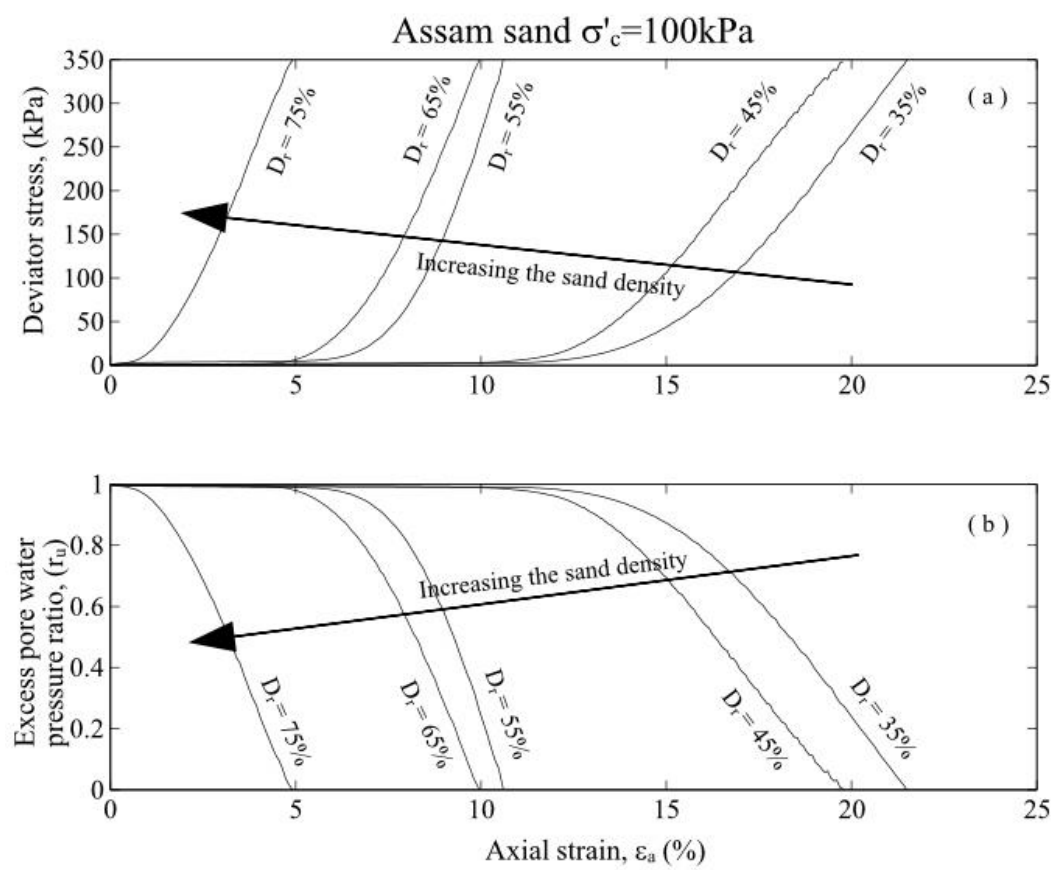

Figure 17: Post liquefaction response of Assam sand (CSR=0.15). Variation of: (a) deviator stress; and (b) excess pore water pressure ratio $\left(r_{u}\right)$ with axial strain (Test MR-50, MR-51, MR-53, MR-55 and MR-57).
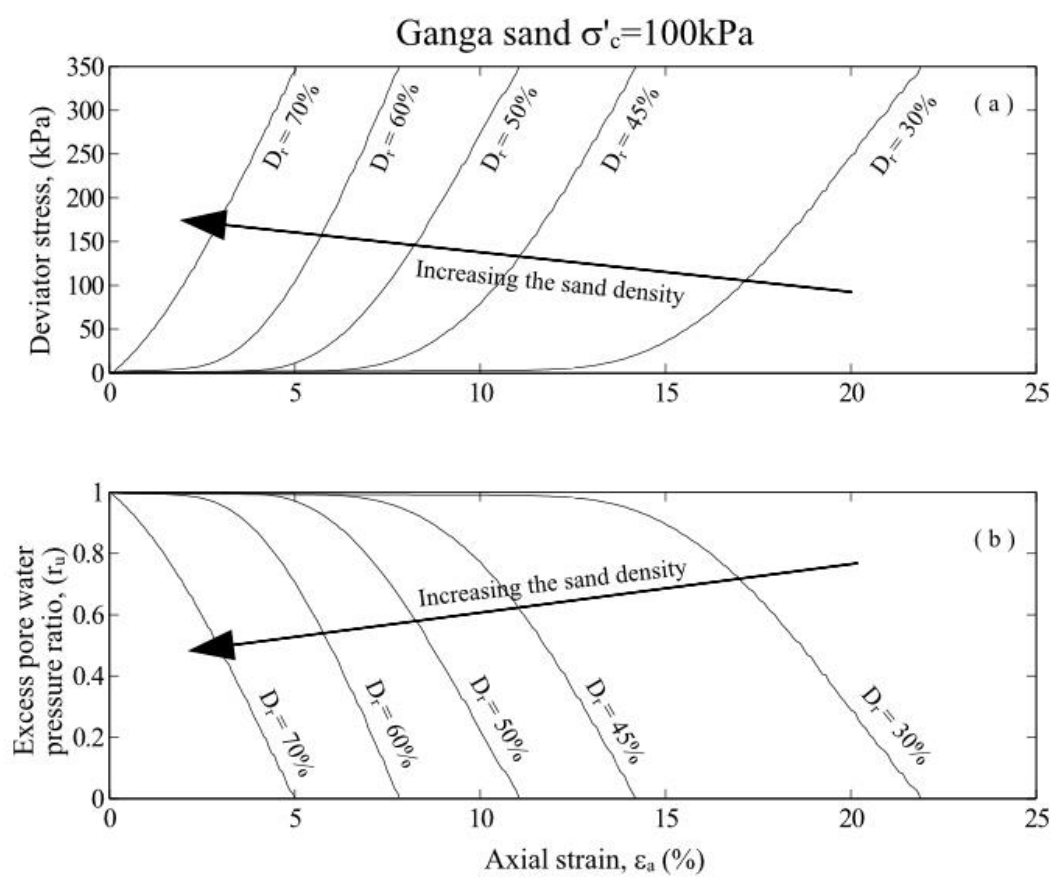

Figure 18: Post liquefaction response of Ganga sand (CSR=0.15). Variation of: (a) deviator stress; and (b) excess pore water pressure ratio $\left(r_{u}\right)$ with axial strain (Tests MR-58, MR-60, MR-63, MR-65 and MR-67).

As discussed earlier, when the liquefied sand is sheared monotonically, the sand particles are again brought to contact with each other and, as a consequence, inter-locking occurs after reaching a certain amount of axial strain. Figure 19(a) shows a typical axial stress-axial strain 
curve of liquefied sand. During the initial stage of monotonic loading, the stiffness of the sand is almost negligible, indicating practically no shear strength; with continuous straining, the strength is mobilised when a certain level of axial strain is reached (in the figure, this is about $4 \%$ axial strain). In order to study the post-liquefaction behaviour, this axial strain-deviator stress curve is converted to shear strain-shear stress curve which is shown in Figure 19(b). The following equations were employed in the conversion process:

$$
\begin{aligned}
\tau & =\frac{q}{2} \\
\gamma & =(1+v) \varepsilon_{a}
\end{aligned}
$$

where $\tau$ and $\gamma$ are shear stress and shear strain, respectively, while $v$ is the Poisson's ratio which has been taken as 0.5 for undrained condition.

In the plot shown in Figure 19(b), the term $G_{2}$ corresponds to the critical state shear modulus during post-liquefaction stage of sand, which is discussed later in this section. To investigate the post-liquefaction stress-strain behaviour of sand further, a portion of the plot is magnified to clearly see the response of liquefied sand at the beginning of the shearing (Figure 19(c)). It is clear that the curve has an initial slope (initial shear modulus) at the beginning of the loading, which is called $G_{1}$. In terms of excess pore water response, as depicted in Figures 19(d) and 19(e), the excess pore water pressure ratio starts to decrease gently from the initial value of 1.0 at the start of monotonic loading. When a certain level of axial strain is reached, the excess pore water pressure ratio decreases significantly (magnified in Figure 19(f)). It is clear that this level of shear strain when the excess pore water pressure starts to significantly decrease is the same level of shear strain when the shear stress increases remarkably. This shear strain is called $\gamma_{\text {post-dilation }}$, corresponding to the strain when the stiffness increases dramatically. As Figure 19(f) illustrates, this point is the intersection of two tangent lines in the excess pore water pressure ratio versus shear strain curve. Dash (2010) approximated a similar parameter to be related to the shear strength at a very small level, $(1 \mathrm{kPa})$ and referred to it as the take-off shear strain with the assumption that it was the start of the dilative response of liquefied sand. Based on the tests performed, during the post-liquefaction process, the sand sample starts to dilate when the excess pore water starts to dissipate. This dilation can happen at different levels of shear stress. Therefore, the point where the excess pore water starts to dissipate was chosen to represent the post-dilation shear strain of the sample.

Looking back at Figures 15-18, it can be noticed that the post-liquefaction response of initially very dense samples is different from that of medium-dense and loose samples. For example, the response of soil with initial relative density of $80 \%$ is different from those of similar sands but with lower relative densities. It seems that very dense sand has significant stiffness from the beginning of monotonic loading $\left(\gamma_{\text {post-dilation }}=0\right)$. The void ratio in very dense sand is almost minimum (the soil structure mainly consisted of sand particles). Therefore, during cyclic shearing, the amount of water between the sand particles in dense sample is less due to the minimum void ratio and the sand particles do not completely float in water (there is a small contact between sand particles) which is termed as cyclic mobility. As a consequence there is no initial zero stiffness for very dense sand in the post-liquefaction behaviour. Alternatively, because of the dense packing, dilatancy immediately occurs in dense liquefied sand once shearing is applied. 

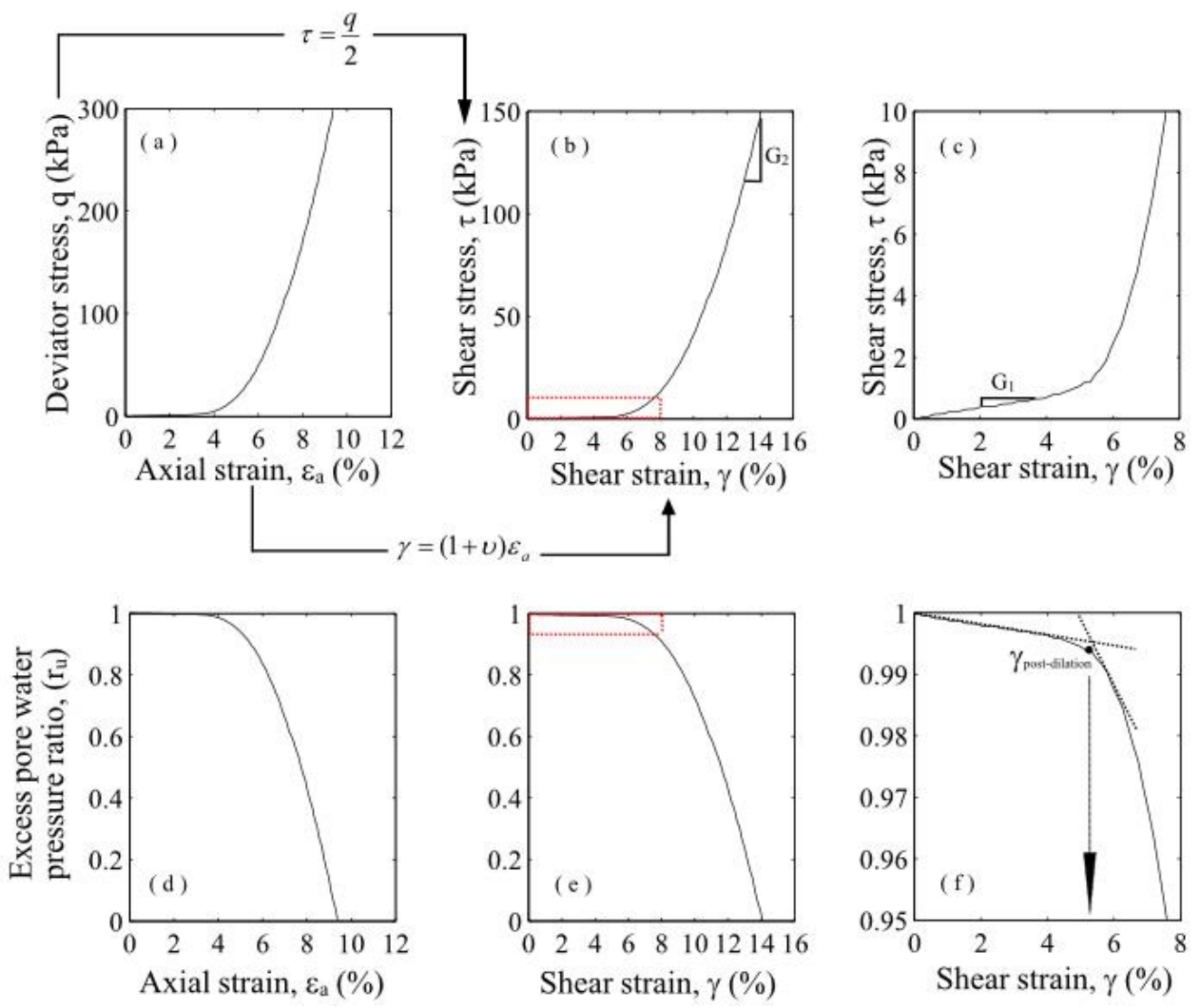

Figure 19: Example of post-liquefaction stress-strain and excess pore water pressure ratio of Redhill-110 sand in normal and magnified situation: (a) axial strain versus deviator stress; (b) shear strain versus shear stress; (c) magnified shear strain-shear stress curve; (d) axial strain versus excess pore water pressure ratio; (e) shear strain versus excess pore water pressure ratio; and (f) magnified shear strain versus excess pore water pressure ratio.

As shown in Figure 20, the stress-strain behaviour of liquefied sand can be modelled as bilinear curve and can be defined in terms of three parameters: the initial shear modulus $\left(G_{1}\right)$, critical state shear modulus $\left(G_{2}\right)$, which are shown in Figure 20(a); and post-dilation shear strain $\left(\gamma_{\text {post-dilation }}\right)$, the shear strain when the soil starts to dilate in post-liquefaction state, which is shown in Figure 20(b). From Figures 15-18, it would appear that each of these parameters are functions of the initial relative density of the sands discussed below.

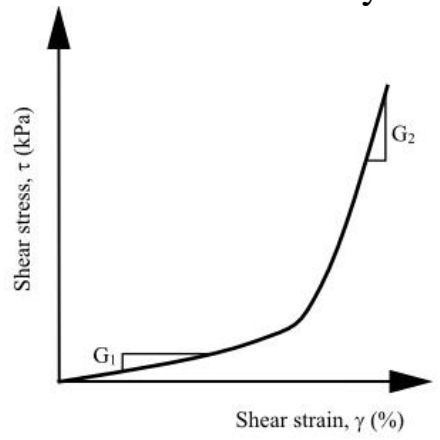

(a)

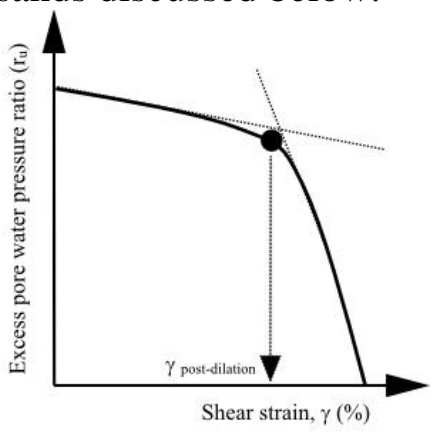

(b)

Figure 20: Post-liquefaction behaviour of liquefied sand: (a) shear strain versus shear stress; and (b) shear strain versus excess pore water pressure ratio. 


\section{Post-dilation shear strain $\left(\gamma_{\text {post-dilation }}\right)$}

In the excess pore water pressure ratio versus shear strain plot, the magnitude of the shear strain when the sand starts to dilate is called "post-dilation shear strain". Looking at Figures 15(b)-18(b) the location of post-dilation shear strain depends on the relative density of sand. To elucidate on such a relation, the effect of the initial relative density of the sands on $\gamma_{\text {post-dilation }}$ is investigated, and the results for tests with effective confining pressure of about $100 \mathrm{kPa}(97-$ $105 \mathrm{kPa}$ ) are summarised in Figure 21. As can be seen, this strain level generally decreases as the relative density of the sand increases. The void ratio of very dense sand is almost minimum (the soil structure mainly consisted of sand particles) and therefore, during liquefaction, the amount of water between the sand particles is less due to the very small void ratio and the sand particles are not completely floating in the water medium. As a consequence, there is no initial zero stiffness for very dense sand in the post liquefaction behaviour. Moreover, dilatancy immediately occurs in dense sand and shear strength is recovered immediately with particle rearrangement.

Based on the experimental data, the correlation between post-dilation shear strain (in \%) and relative density can be expressed by Equation (5) where $\mathrm{D}_{\mathrm{r}}$ is in \%:

$$
\gamma_{\text {post-dilation }}=43.4-9.8 \ln \left(D_{r}\right)
$$

As the samples considered in the series of tests have relative densities between $30 \%$ and $75 \%$, the above correlation is valid only within this range (i.e. $30 \%<D_{r}<75 \%$ ).

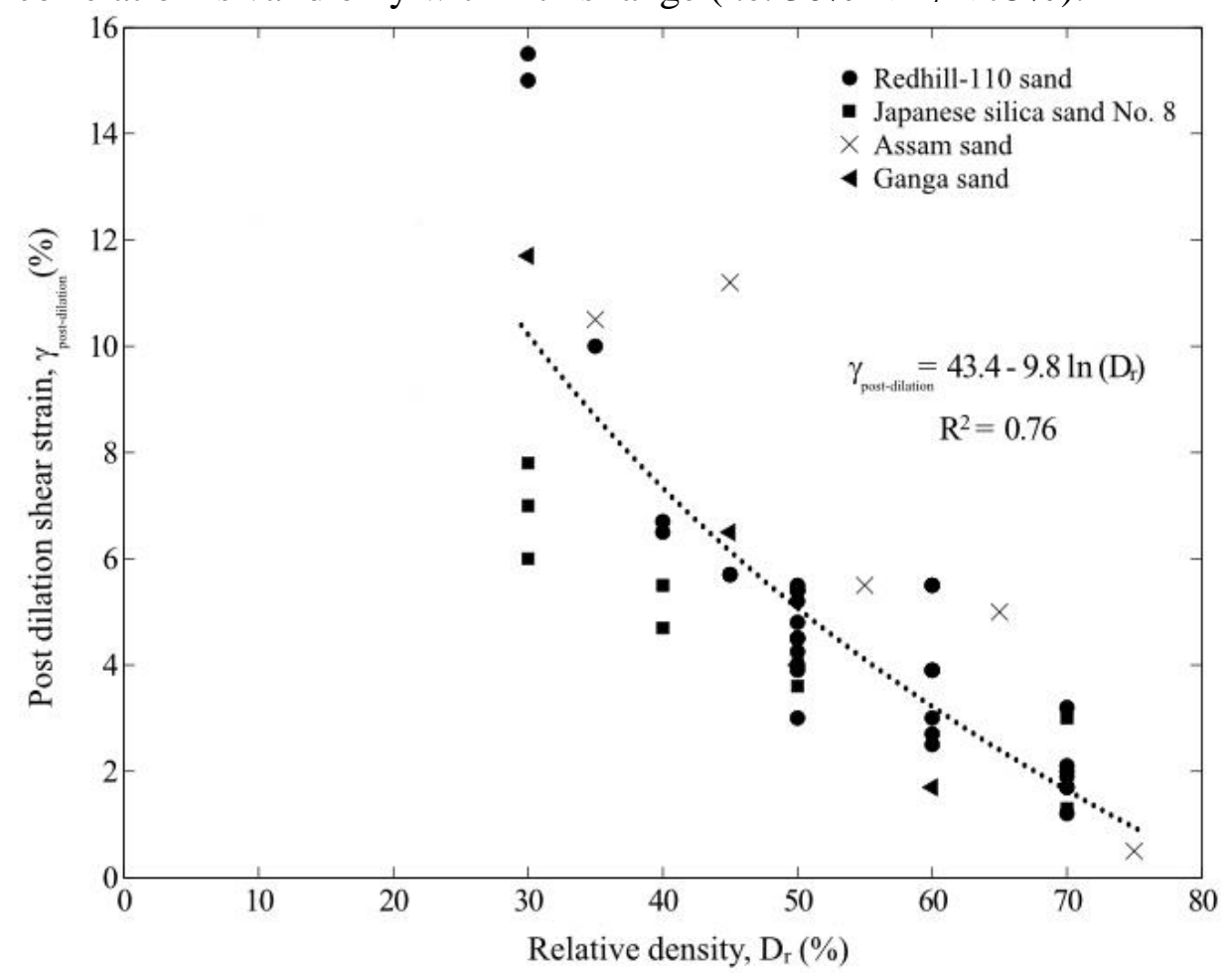

Figure 21: Post-dilation shear strain versus relative density relation $\left(\sigma_{c}^{\prime} \approx 100 \mathrm{kPa}\right)$.

The post-dilation shear strain is defined as a point when the excess pore water pressure starts to decrease significantly during monotonic loading (Rouholamin, 2016). On the other hand, take-off shear strain defined in Dash (2010), Lombardi et al (2017) is related to the shear strength at a very small level, $(1 \mathrm{kPa})$ with the assumption that it is the onset of the dilative response of liquefied sand. After investigation the authors couldn't find a significant difference between these two parameters. 


\section{Initial shear modulus $\left(G_{1}\right)$}

Dash (2010) suggested that the initial shear modulus can be estimated by Equation (6);

$$
G_{1}=\frac{1}{\gamma_{t o}}
$$

where $\gamma_{\text {to }}$ is the take-off shear strain corresponding to $1 \mathrm{kPa}$ of shear stress and $G_{1}$ is the initial shear modulus in unit of $\mathrm{kPa}$. In this study, the value of the initial shear modulus was read directly from the shear stress-shear strain curve of liquefied sand, as shown for example in Figure 19(c). The values of $G_{1}$ are plotted against the relative density, as shown in Figure 22, where it can be seen that when the relative density increases, the initial shear modulus $G_{1}$ increases. Under constant volume condition, denser sand samples have more particles present; when they are sheared, the shear resistance prior to the post-dilation strain is expected to be larger as more particles are available to provide the resistance.

The correlation derived from the experiments between the relative density and $G_{1}$ (in $\mathrm{kPa}$ ) is given be Equation (7) where $\mathrm{D}_{\mathrm{r}}$ is in $\%$.

$$
G_{1}=2.8 e^{\left(0.04 D_{r}\right)}
$$

As mentioned above, this correlation is valid only for the relative densities considered in the test series (i.e. $30 \%<D_{r}<75 \%$ ).

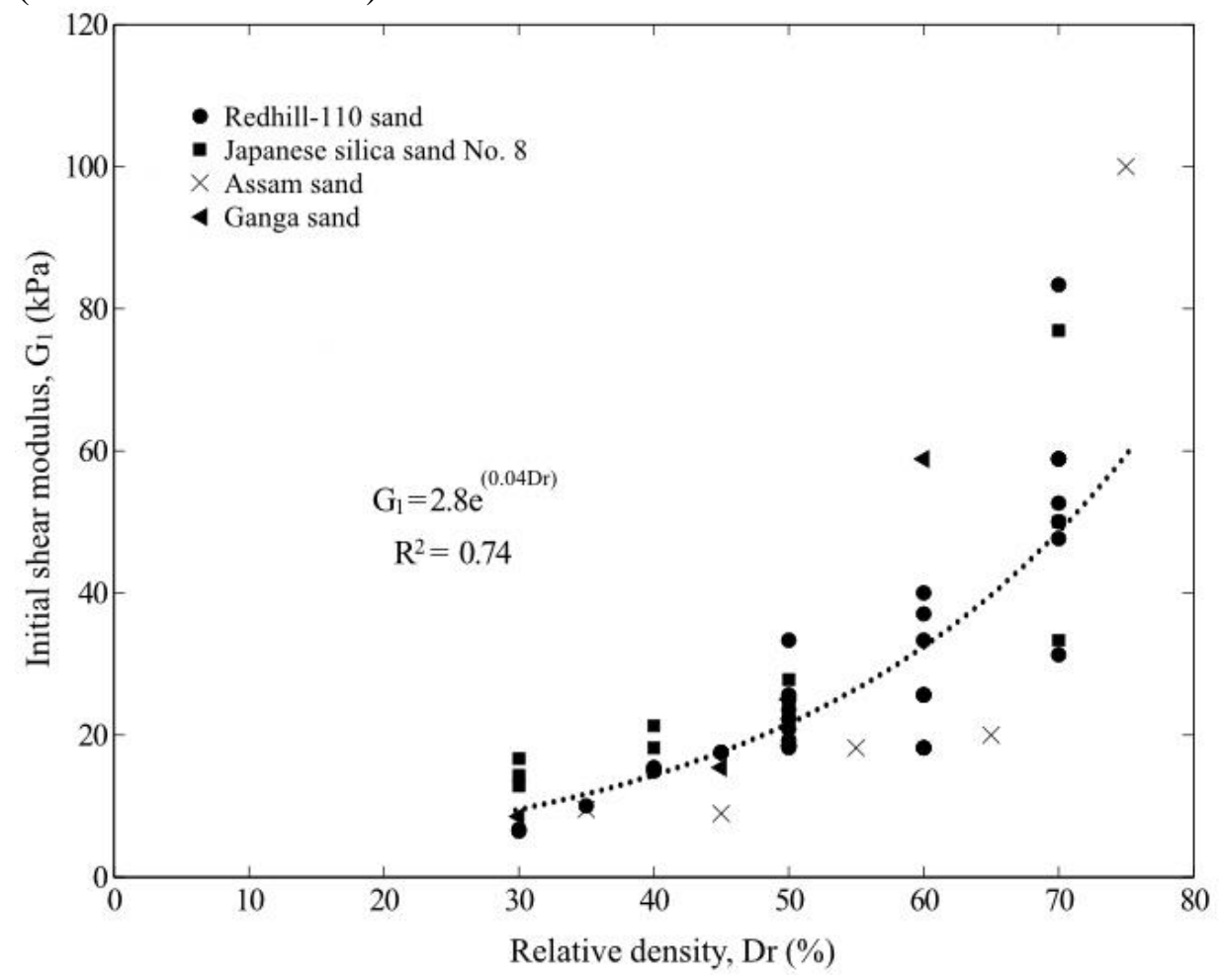

Figure 22: Initial shear modulus of post liquefied sand $\left(G_{1}\right)$ versus relative density relation

$$
\left(\sigma_{c}^{\prime} \approx 100 \mathrm{kPa}\right) \text {. }
$$

\section{Critical state shear modulus $\left(G_{2}\right)$}

The critical state shear modulus of the liquefied sand was calculated directly from the undrained monotonic test, as illustrated in Figure 19(b). The post-liquefaction response for liquefied soil is dilative and as the soil sample is sheared following the critical state line, the obtained shear modulus is called "critical state shear modulus". The values obtained for all the sands tested were plotted versus relative density, as shown in Figure 23. From the graph, there 
is a linear relationship between the relative density and the critical state shear modulus, with $G_{2}$ increasing with the increase in the soil's relative density. By considering constant volume condition, dense samples would show significant dilative tendency which would be manifested with development of negative pore water pressure; on the other hand, looser samples would show lesser tendency to dilate, and therefore lesser shear modulus. Based on the trend observed, the correlation between the critical shear modulus $\mathrm{G}_{2}$ in $\mathrm{kPa}$ and soil relative density ( $\mathrm{D}_{\mathrm{r}}$ in \%) is given by Equation (8).

$$
G_{2}=150 D_{r}+343.7
$$

Again, the above correlation is valid only for the relative densities considered in the test series (i.e. $30 \%<D_{r}<75 \%$ ).

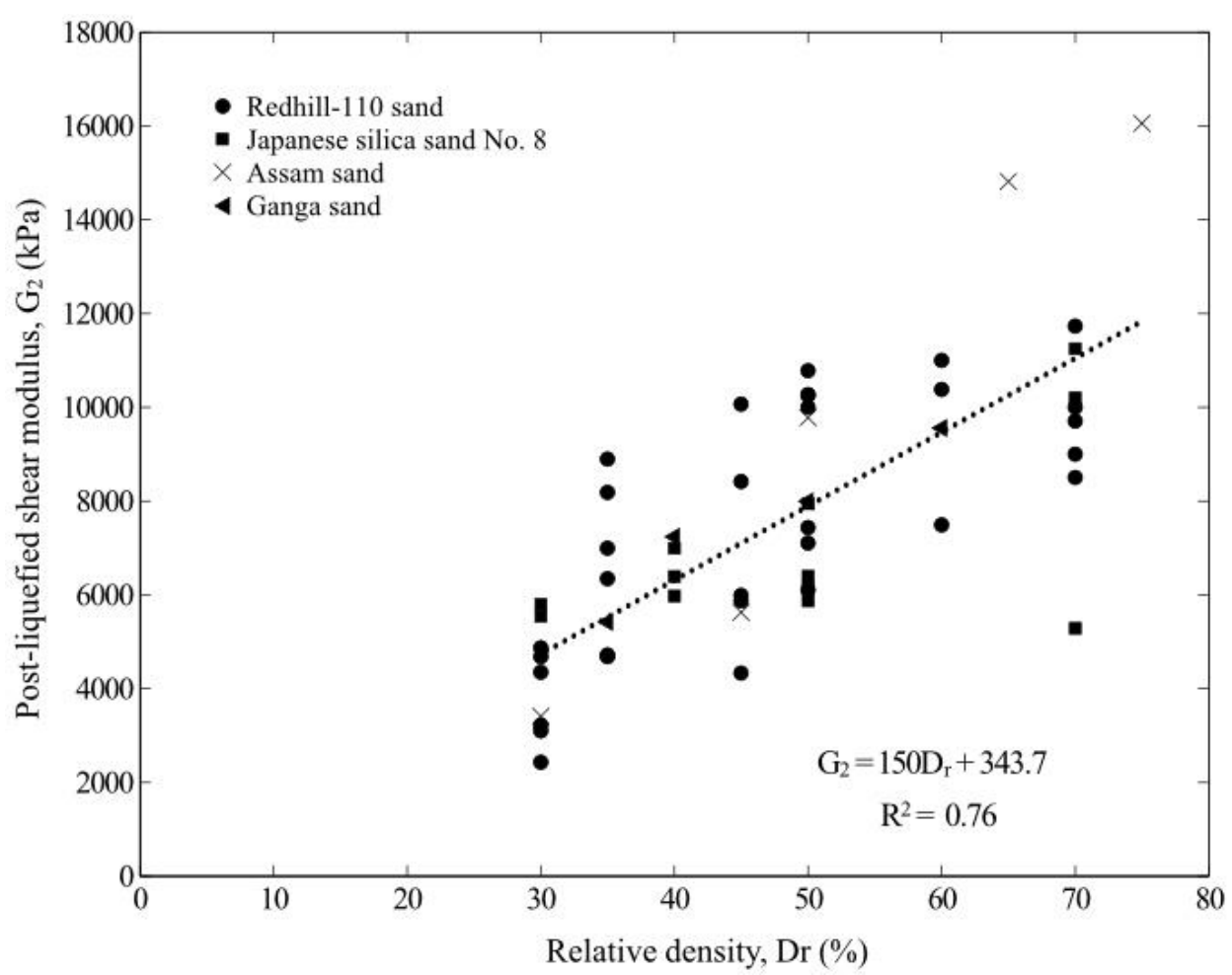

Figure 23: Critical state shear modulus $\left(G_{2}\right)$ versus relative density relation $\left(\sigma_{c}^{\prime} \approx 100 \mathrm{kPa}\right)$.

\section{Effect of initial confining stress}

Initial confining stress has a strong influence on soil shear modulus $(G)$ as presented in the literature (Papadimitriou et al. 2001). However, initial confining stress may have different effect on the critical state shear modulus $(G 2)$ which is one of the post liquefaction parameter. In order to investigate the effect of initial effective confining stress on the post-liquefaction behaviour of sands, Japanese silica sand No. $8\left(D_{r}=50 \%\right)$ was tested under three different levels of initial effective confining stress: 50,100, and 150kPa. As shown in Figure 24, the confining stress affects the stress-strain relation of the liquefied sand, especially the slope of the curve when the sand dilates, which is denoted as the critical state shear modulus $\left(G_{2}\right)$. With the increase in the level of confining stress, $G_{2}$ is increased. Such response was also reported by Lombardi, (2014) and Lombardi et al. (2014) on their tests on Redhill-110 sand. However, because of the limited tests conducted involving other confining stress levels, the effect of effective confining stress on the post-liquefaction behaviour is not pursued further in this study. 


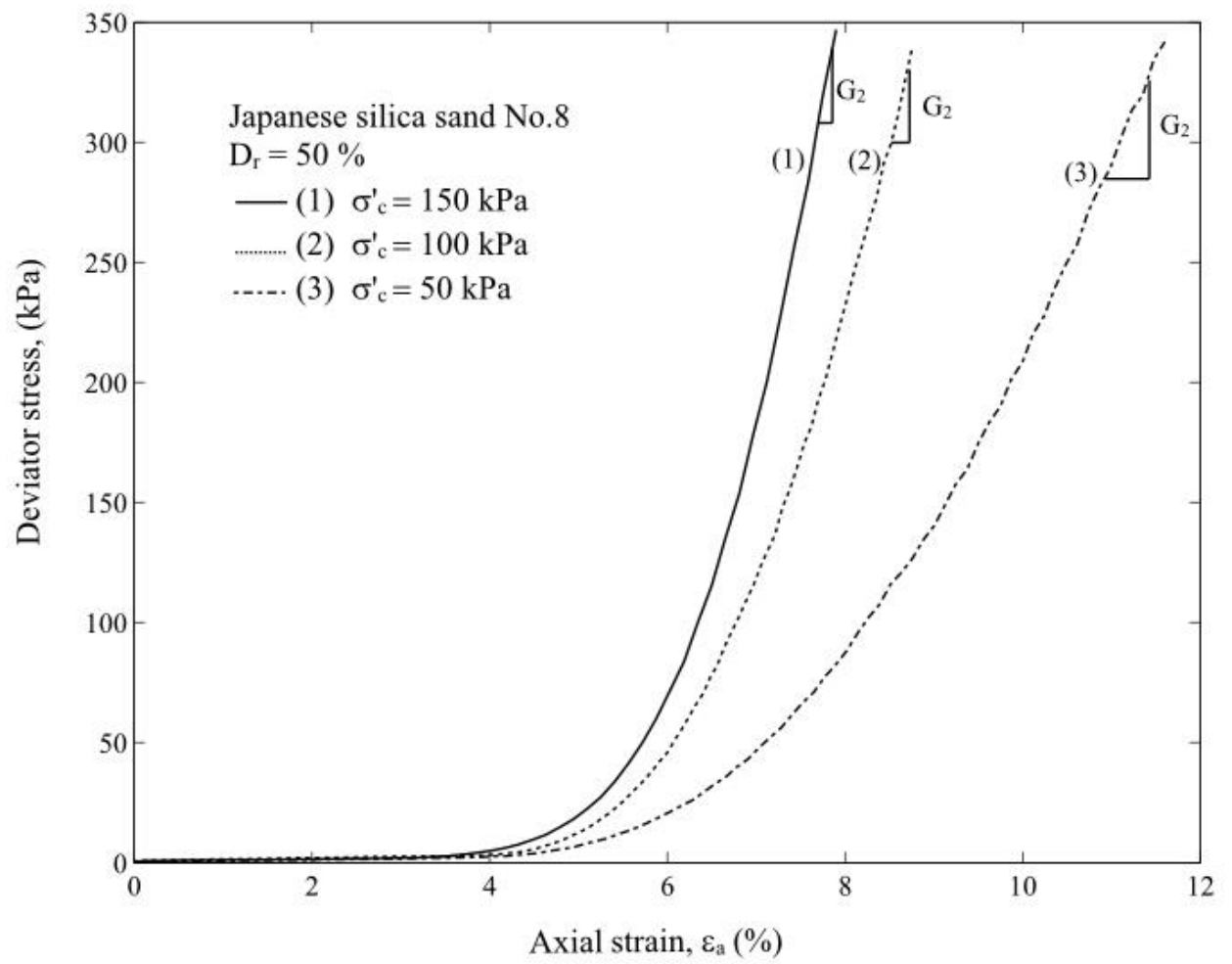

Figure 24: The effect of initial effective confining stress on post liquefaction behaviour of Japanese silica sand No. 8.

\section{Shear modulus changes from pre- to post-liquefaction stage}

At the initial state of the saturated sand (prior to the multi-stage test), the maximum shear modulus of the sand can be defined as $G_{0}$, i.e. shear modulus at small strain. In this paper, the $G_{0}$ for all test specimens was calculated from the first cycle of loading during the cyclic loading phase. This is illustrated in Figure 25 as the slope of the first cycle of the stress-strain curve (converted shear stress versus shear strain). As the soil softens due to excess pore water pressure generation, the mean effective stress decreases and approaches zero, resulting in very low stiffness of the liquefied soil. When the liquefied sand is subjected to undrained monotonic load, the sand initially shows very low initial stiffness when compared to its maximum shear modulus. From Figure 26, the initial shear modulus after liquefaction (i.e. $G_{1}$ ) is reduced to 1/10000 of the maximum shear modulus. Similar results were presented by Yasuda et al. (1995, 1998). During the post-liquefaction monotonic loading, the liquefied sand gradually recovers its stiffness. The critical state shear modulus (i.e. $G_{2}$ ) obtained is about $1 / 10$ of the maximum shear modulus. It should be noted that these results are from the undrained soil element tests; however, in real grounds where drainage is possible, the critical state shear modulus would reach the maximum shear modulus after sometime, with the dissipation of excess pore water pressure. The critical shear modulus may even be exceeded, if the sand densifies as a result of re-consolidation. 


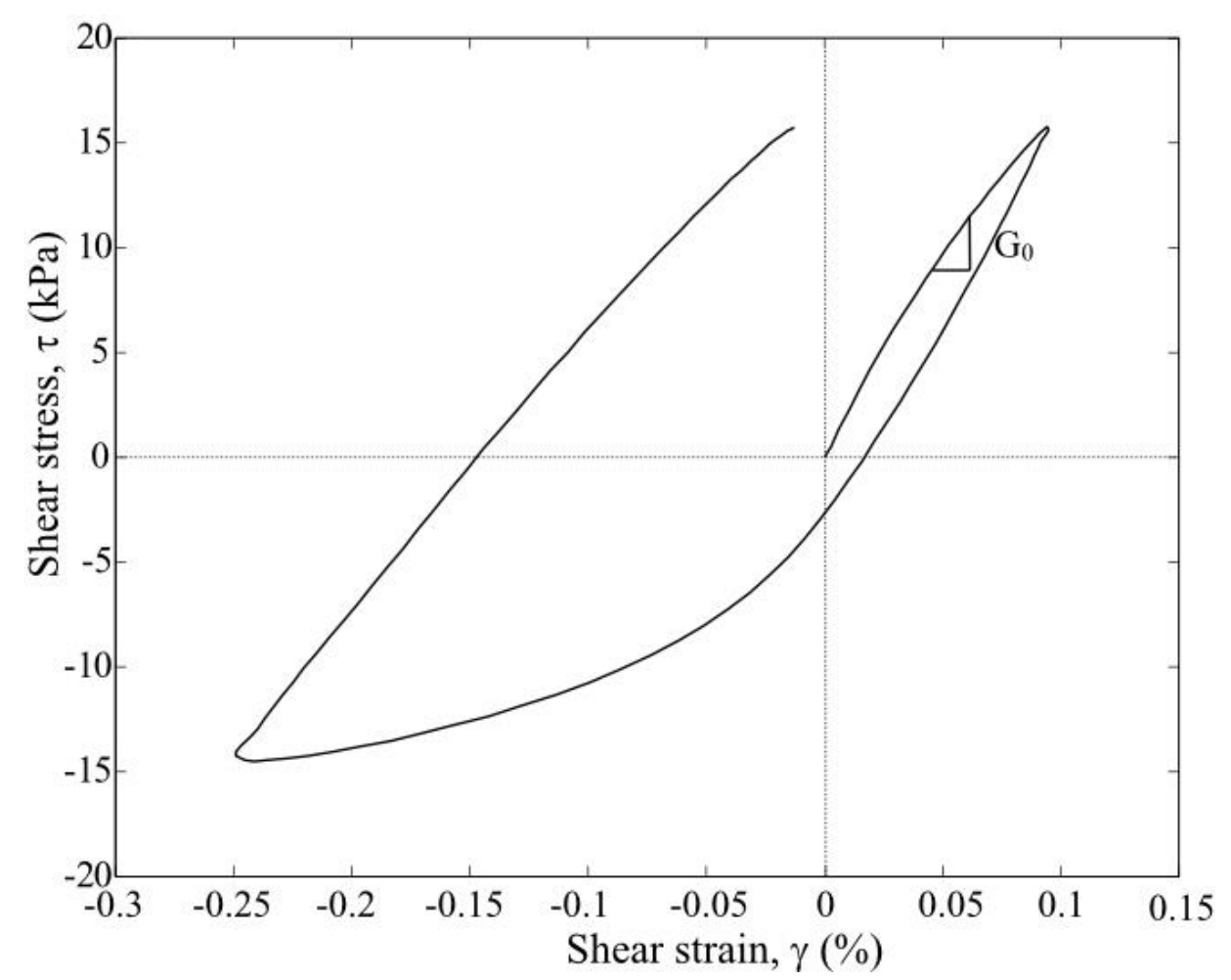

Figure 25: $G_{0}$ measured from the first cycle of the shear stress versus shear strain during cyclic loading.

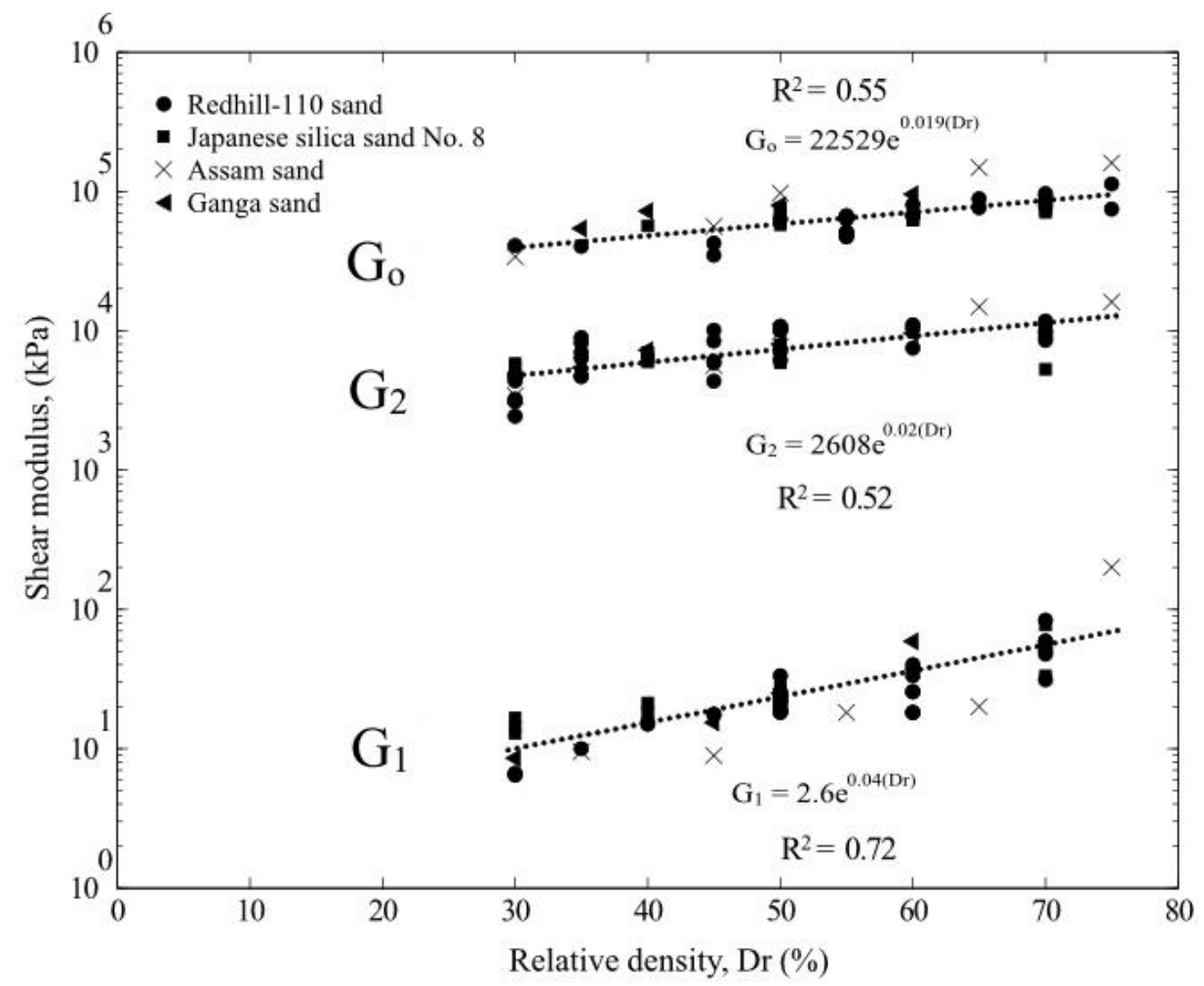

Figure 26: Changes in shear modulus before test, during liquefaction and during critical state. 


\section{Concluding remarks}

As liquefaction occurs due to excess pore water pressure generation, the effective stress decreases. As a consequence, the shear modulus of the sand sample drops from the maximum shear modulus to a very low value (nearly zero). When the liquefied sand is monotonically sheared, the liquefied sand recovers its stiffness gradually in a manner which depends on the initial relative density of the sample. Based on multi-stage testing conducted on four different types of clean sands, the stress-strain behaviour of liquefied sand can be modelled as bi-linear curve which is defined in terms of three parameters: the initial shear modulus $\left(G_{1}\right)$, critical state shear modulus $\left(G_{2}\right)$, and post-dilation shear strain $\left(\gamma_{\text {post-dilation }}\right)$, which is defined as the shear strain when the soil starts to dilate in post-liquefaction state. It was shown that each of these post liquefaction parameters are function of the initial relative density of the sands. By increasing the relative density, $G_{1}$ and $G_{2}$ would increase; however, $\gamma_{\text {post-dilation }}$ would decrease.

Based on the test results, correlations between these parameters and relative density were established. Thus, if the relative density of sand is estimated empirically from, for example, penetration resistance or any other means, the three post-liquefaction parameters can be approximated and the post-liquefaction behaviour can be defined.

As soil liquefies, the initial shear modulus of sand $\left(G_{1}\right)$ would be reduced to about $1 / 10000$ of the maximum shear modulus $\left(G_{0}\right)$. During the post-liquefaction monotonic loading, the liquefied sand gradually recovers its stiffness. The critical state shear modulus $\left(G_{2}\right)$ obtained is about $1 / 10$ of the maximum shear modulus.

This paper described the post-liquefaction response of sand in terms of stress-strain curve. This curve can be used in evaluating lateral spreading of liquefied soil, liquefaction-induced settlements of structures and other liquefaction-related ground deformations. This curve can also be converted to p-y curve in order to analyse soil-structure interaction using Winkler method. Thus, the post-liquefaction behaviour of sand can be examined through the simplified stress-strain relation presented in this paper.

\section{Acknowledgements}

This work is part funded by the EPSRC (Engineering and Physical Sciences Research Council, United Kingdom) through the grant EP/H015345/2.

\section{References}

ASTM-D4253, Standard Test Methods for Maximum Index Density and Unit Weight of Soils Using a Vibratory Table.

ASTM-D4254, Standard Test Methods for Minimum Index Density and Unit Weight of Soils and Calculation of Relative Density.

ASTM-D854, Standard Test Methods for Specific Gravity of Soil Solids by Water Pycnometer. Bouckovalas, G.D., Andrianopoulos, K.I. and Papadimitriou, A.G., (2003), A critical state interpretation for the cyclic liquefaction resistance of silty sands, Soil Dynamics and Earthquake Engineering 23, pp. 115-125.

Dash, S. (2010). Lateral pile-soil interaction in liquefiable soils, PhD Thesis, University of Oxford.

El Takch, A., Sadrekarimi, A. and El Naggar, H. (2016). Cyclic resistance and liquefaction behavior of silt and sandy silt soils, Soil Dynamics and Earthquake Engineering 83, 98-109. 
Hyodo, M., Hyde, A.F.L. \& Aramaki, N. (1998). Liquefaction of crushable soils. Geotechnique, 48(4), 527-543.

Ishihara K. (1993). Liquefaction and flow failure during earthquakes. Géotechnique, 43(3),351-451. http://dx.doi.org/10.1680/geot.1993.43.3.351.

Iwasaki, T. (1986), Soil liquefaction studies in Japan: state of the art. Journal of Soil Dynamics and Earthquake Engineering, Vol. 5, No. 1.

Kamata, T., Tsukamoto, Y. and Ishihara, K, (2009), Undrained shear strength of partially saturated sand in Triaxial tests, Bulletin of the New Zealand society for earthquake engineering, Vol. 42, No. 1.

Kokusho, T., Hara, T. \& Hiraoka, R. (2004). Undrained shear strength of granular soils with different particle gradation. Journal of Geotechnical and Geoenvironmental Engineering, 130(6), 621-629.

Lombardi, D., (2014). Dynamics of pile-supported structures in seismically liquefiable soils (Ph.D. thesis) University of Bristol, UK.

Lombardi, D., Bhattacharya, S., Hyodo, M. \& Kaneko, T. (2014). Undrained behaviour of two silica sands and practical implications for modelling SSI in liquefiable soils, Soil Dynamics and Earthquake Engineering 66, 293-304.

Lombardi, D., and Bhattacharya, S. (2014), Modal analysis of pile supported structures during seismic liquefaction, Earthquake Engineering and Structure Dynamic, 43:119-138.

Lombardi, D., Dash, SR., Bhattacharya, S., Ibraim, E., Wood, DM., Taylor, CA., (2017). Construction of simplified design p-y curves for liquefied soils. Geotechnique. http://dx.doi.org/10.1680/igeot.15.P.116

Mohamad, R. and Dobry, R. (1986), Undrained monotonic and cyclic triaxial strength of sand, Journal of Geotechnical Engineering, Vol. 112, No.10.

Papadimitriou AG, Bouckovalas GD, Dafalias YF. Plasticity model for sand under small and large cyclic strains. J Geotech Geoenviron Eng 2001;127(11):973-83

Port and Harbour Research Institute (1997). Handbook of Liquefaction Remediation in Reclaimed Lands, Balkema.

Roscoe, K.H., Schofield, A.N. \& Wroth, C.P. (1958). On the yielding of soils, Géotechnique, 8(1), 22-53. http://dx.doi.org/10.1680/geot.1958.8.1.22.

Rouholamin, M. (2016). An experimental investigation of transient dynamics of pile-supported structures in liquefiable soils. PhD thesis, University of Surrey, UK.

Seed, H.B. \& Lee, K.L. (1966). Liquefaction of saturated sands during cyclic loading, J Soil Mech Found Eng, ASCE, 92(SM6):105-34.

Shamoto, Y., Zhang, J.M. \& Goto, S. (1997). Mechanism of large post-liquefaction deformation in saturated sand. Soils and Foundations, 37(2), 71-80.

Sitharam, T.G., Vinod, J.S. \& Ravishankar, B.V. (2009). Post-liquefaction undrained monotonic behaviour of sands: experiments and DEM simulations. Géotechnique, 59(9), 739-749. 
Sivathayalan, S Vaid, YP. (2004). Cyclic resistance and post liquefaction response of undisturbed in-situ sands. In: Proceedings of the 13th world conference on earthquake engineering: Vancouver B.C. (Canada); August 1-6. p. 2940.

Thomas, J. (1992). Static, cyclic and post liquefaction undrained behaviour of Fraser river sand, PhD Thesis, University of British Columbia.

Wang, Y., and Wang, YL. (2017), Liquefaction characteristics of gravelly soil under cyclic loading with constant strain amplitude by experimental and numerical investigations, Soil Dynamics and Earthquake Engineering 92, 388-396.

Vaid, Y.\& Thomas, J. (1995). Liquefaction and post liquefaction behavior of sand, Journal of Geotechnical Engineering, ASCE, 121(2), 163-173.

Yasuda, S. and Soga, M. (1984) Effect of frequency on undrained strength of sands, Proc. 19th Nat. Conf. Soil Mech. Found. Eng, pp. 549-550 (in Japanese).

Yasuda, S., Yoshida, N., Masuda, T., Nagase, H., Mine, K. \& Kiku, H. (1995). Stress-strain relationships of liquefied sands. Earthquake Geotechnical Engineering. Rotterdam: Balkema pp. 811-816.

Yasuda, S., Terauchi, T., Morimoto, H., Erken, A. \& Yoshida, N. (1998). Post liquefaction behaviour of several sands, $11^{\text {th }}$ European Conference on Earthquake Engineering, Balkema, Rotterdam.

Yasuda, S., Yoshida, N., Kiku, H., Adachi, K. \& Gose, S. (1999). A simplified method to evaluate liquefaction-induced deformation, Proc. Earthquake Geotechnical Engineering (Seco e Pinto, P., Ed) Balkema, Rotterdam. Vol. 2, 555-566. 